\title{
Field Survey and Archival Research for the Rosillo Creek Battleground Area, Southeast San Antonio, Texas
}

I. Waynne Cox

Follow this and additional works at: https://scholarworks.sfasu.edu/ita

Part of the American Material Culture Commons, Archaeological Anthropology Commons, Environmental Studies Commons, Other American Studies Commons, Other Arts and Humanities Commons, Other History of Art, Architecture, and Archaeology Commons, and the United States History Commons

Tell us how this article helped you.

This Article is brought to you for free and open access by the Center for Regional Heritage Research at SFA ScholarWorks. It has been accepted for inclusion in Index of Texas Archaeology: Open Access Gray Literature from the Lone Star State by an authorized editor of SFA ScholarWorks. For more information, please contact cdsscholarworks@sfasu.edu. 
Field Survey and Archival Research for the Rosillo Creek Battleground Area, Southeast San Antonio, Texas

\section{Creative Commons License}

(c) (1) (8)

This work is licensed under a Creative Commons Attribution-NonCommercial 4.0 International License 
Field Survey and Archival Research for the Rosillo Creek Battleground Area, Southeast San Antonio, texas

9. Wayne $C_{o x}$

With an $A_{\text {ppendix by }} D_{\text {ora }}$ Guerra

Center for Archaeological Research The University of Texas at San Antonio Archaeological Survey Report, No. 177

1990 



FIELD SURVEY AND ARCHIVAL RESEARCH FOR THE

ROSILLO CREEK BATTLEGROUND AREA,

SOUTHEAST SAN ANTONIO, TEXAS

I. Waynne Cox

With an Appendix by Dora Guerra

Center for Archaeological Research

The University of Texas at San Antonio®

Archaeological Survey Report, No. 177

1990 
This book is printed on acid-free paper (Cougar No. 1 Opaque Offset).

A list of publications offered by the Center for Archaeological Research can be obtained by sending $\$ 1.00$ to the Center for Archacological Research, The University of Texas at San Antonio, San Antonio, Texas 78285-0658. 


\begin{abstract}
In January 1988, the Center for Archaeological Research, The University of Texas at San Antonio, entered into a contract with Waste Management of North America, Inc., to provide archival research and a field survey of an area in southeast San Antonio designated as the vicinity of the 1813 Battle of Rosillo. Archival and published materials indicate that the actual site is approximately one and a half miles from the current marker. Aside from the conclusion that the battle did not take place at the proposed landfill site, the field survey revealed that the land had been severely altered, leaving nothing of archaeological significance.
\end{abstract}




\section{TABLE OF CONTENTS}

ABSTRACT $\ldots \ldots \ldots \ldots \ldots \ldots \ldots \ldots \ldots \ldots \ldots \ldots \ldots \ldots \ldots \ldots \ldots \ldots \ldots \ldots$

LIST OF FIGURES $\ldots \ldots \ldots \ldots \ldots \ldots \ldots \ldots \ldots \ldots \ldots \ldots \ldots \ldots \ldots \ldots \ldots \ldots \ldots$

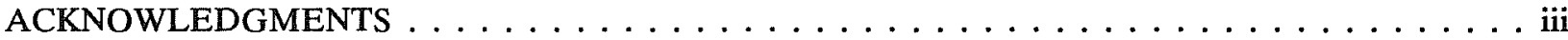

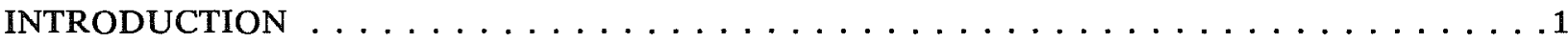

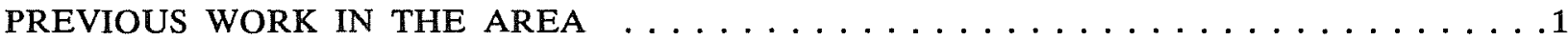

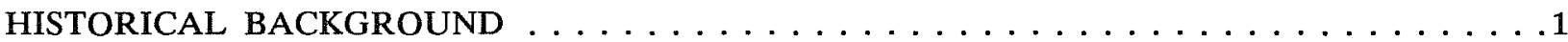

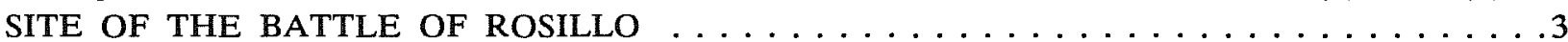

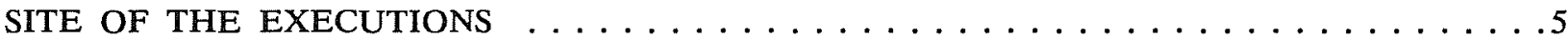

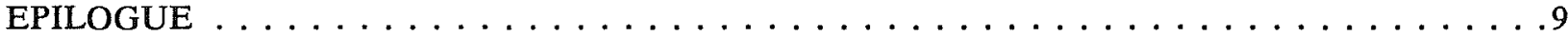

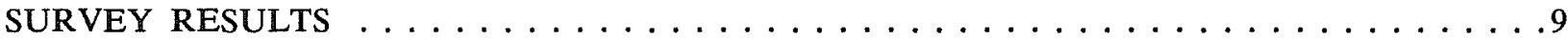

CONCLUSIONS AND RECOMMENDATIONS $\ldots \ldots \ldots \ldots \ldots \ldots \ldots \ldots \ldots \ldots \ldots$

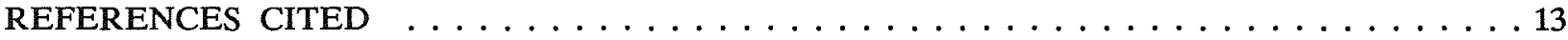

APPENDIX: TRANSLATIONS FROM THE SPANISH PERIOD, 1813-1814 (Dora Guerra) . . . 16

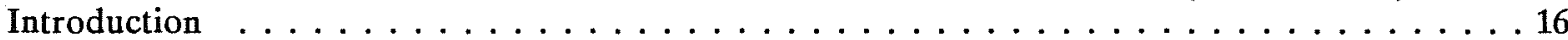

Deposition of Guillermo Saldaña, April $8,1813 \ldots \ldots \ldots \ldots \ldots \ldots \ldots$

Transcription for the Deposition of Guillermo Saldaña $\ldots \ldots \ldots \ldots \ldots \ldots$

Translation for the Deposition of Guillermo Saldaña . . . . . . . . . . . . . . . 19

Deposition of Guillermo Navarro, April 8, $1813 \ldots \ldots \ldots \ldots$. . . . . . . . . . . 20

Transcription for the Deposition of Guillermo Navarro $\ldots \ldots \ldots \ldots \ldots$

Translation for the Deposition of Guillermo Navarro $\ldots \ldots \ldots \ldots \ldots \ldots \ldots$

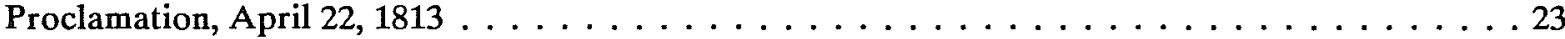

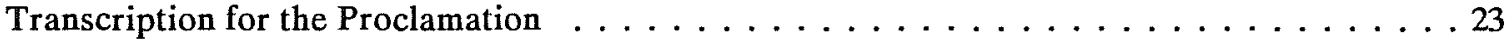

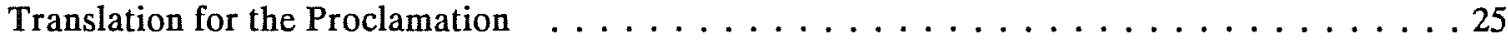

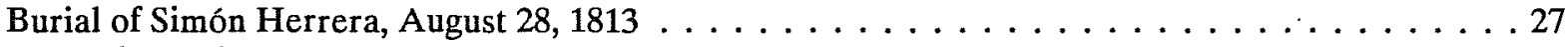

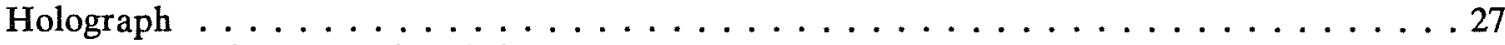

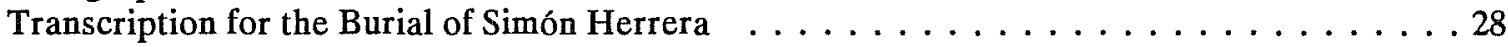

Translation for the Burial of Simón Herrera . . . . . . . . . . . . . . . . . . . . . . . 29

Burial of Manuel Salcedo, August 28, $1813 \ldots \ldots \ldots \ldots \ldots \ldots$

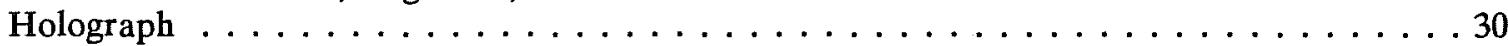

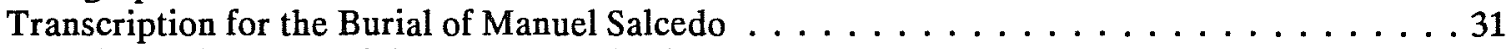

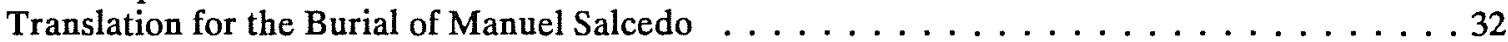

Group Burial of the Rosillo Dead, August $28,1813 \ldots \ldots \ldots \ldots \ldots$

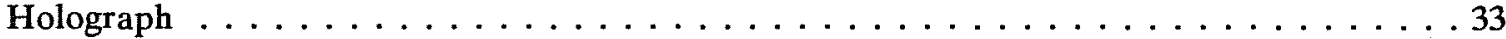

Transcription for the Group Burial of the Rosillo Dead . . . . . . . . . . . . 34

Translation for the Group Burial of the Rosillo Dead . . . . . . . . . . . . . 34

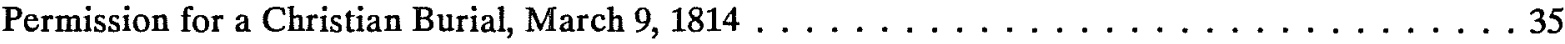

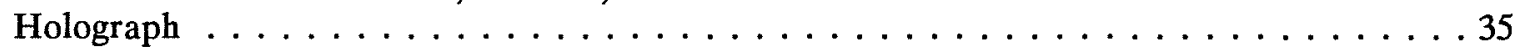

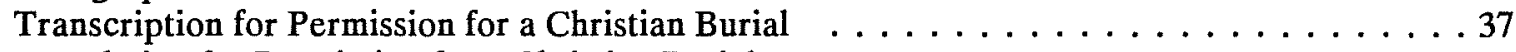

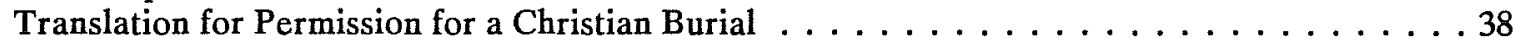

References Cited . . . . . . . . . . . . . . . . . . . 39

\section{LIST OF FIGURES}

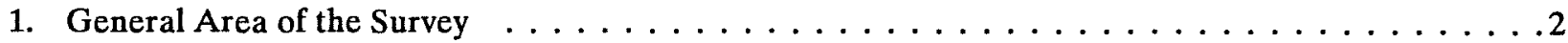

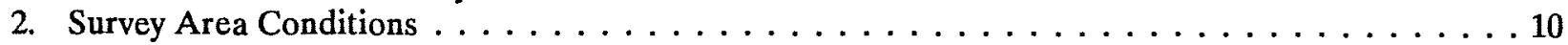

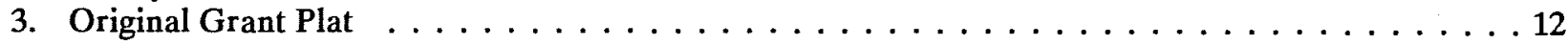




\section{ACKNOWLEDGMENTS}

Dora Guerra, Head of Special Collections, the John Peace Library at The University of Texas at San Antonio, not only contributed the translations included as an appendix to this report, but provided invaluable assistance in locating many early documents. John Ogden Leal, Bexar County archivist, contributed to this project by providing his translations of the San Fernando Cathedral records and helping with the files of the archives. Jesus de la Teja, Archives and Records Division of the General Land Office, Austin, provided the information on the Montez de Oca grant. The author would also like to note the assistance of Felix Almaráz, Henry Guerra, and Richard Santos. The staff of the Daughters of the Republic of Texas Research Library at the Alamo also provided information from their valuable collection. A special thanks to the Southern Texas Archaeological Association (STAA) members Tommy Tomesal, Joan Lloyd, and Clint McKenzie for their assistance during the field survey, the first two provided the metal detectors. Finally to staff members David Hafernik and Kelly Scott for their assistance during the survey. David also produced the illustrations for this report, and Kelly gave the proper rattlesnake count. 



\section{INTRODUCTION}

In January 1988, the Center for Archaeological Research (CAR), The University of Texas at San Antonio (UTSA), entered into a contract with Waste Management of North America, Inc., Central Region, to provide archival research and a field survey of the area near a 1936 Texas Historical Marker (Dooley and Dooley 1985:437) stating:

In this vicinity the Battle of Rosalis was fought on March 28, 1813. Here the Republican Army of the North composed of Anglo-Americans, Mexicans and Indians defeated, with heavy loss of life, Spanish Royalist troops commanded by Manuel de Salcedo, governor of Texas. The prisoners of war were brutally murdered shortly afterwards by order of Colonel Bernardo Gutierrez.

The study area, located at the intersection of South W. W. White Road and Hildebrandt Road (Fig. 1), was being considered as a landfill. An archival search of printed materials, contemporary Spanish records, church burial records, and land grant surveys was conducted, and a pedestrian survey, with VLF-TR metal detection assistance, was undertaken.

\section{PREVIOUS WORK IN THE AREA}

In 1968, a historic burial (41 BX 34), 0.2 miles east of the intersection of Blue Wing Road and old South Flores Road, was reported to the staff of the Witte Museum. Investigation revealed the burial was a male in his mid-twenties approximately five feet seven inches tall; it was felt that the burial was an isolated case. Several buttons and a lead ball date the burial from the early part of the 19th century, however, its distance from the Rosillo battlefield, some five to six miles, indicates it was not related to this battle (Butler 1974; Fox 1983:126-129).

In October 1972, a teacher and his students from Saint Mary's University excavated a cemetery between Rosillo Creek and Salado Creek west of South W. W. White Road. Later investigations and collections indicate that the cemetery dates from the Archaic Austin phase (CAR-UTSA site files 41 BX 176). Three other sites in the area (41 BX 358, $41 \mathrm{BX} 359$, and $41 \mathrm{BX} 360$ ) are reported as prehistoric lithic scatters, i.e., chert flakes which indicate previous occupation and/or use of the area by prehistoric peoples (CAR-UTSA site files).

\section{HISTORICAL BACKGROUND}

The 19th century was tempestuous for the Spanish empire in the Americas. The waning power of Spain, the transference of Louisiana to the United States, and the rising wave of Mexican independence made Spanish Texas appear ripe for the filibustering ambitions of the United States. The account of the Gutiérrez-Magee Expedition reveals some of the tension of the times.

In August 1812, José Bernardo Maximiliano Gutiérrez de Lara, a Mexican rebel, united with Lieutenant Augustus W. Magee and crossed the Sabine River with 130 men and captured Nacogdoches. Recruiting Mexican, Indian, and American supporters as they progressed, they occupied La Bahía (Goliad) on November 7, where Governor Manuel Maria de Salcedo placed them under siege. After the death of Magee, February 6, 1813, Samuel Kemper assumed command. After two defeats, the Spanish army retreated to San Antonio. The following month, Kemper, with a strength of about 800 men, marched toward the capital, engaging the Royalist army of 1200 under command of General Simón de Herrera, at what would later become known as the Battle of Rosillo, or Rosalis. San Antonio surrendered unconditionally on April 1, and on April 3, 14 loyalist officers, including Governor Salcedo, General Herrera, and Nemesio de Salcedo y Salcedo, were executed. This so appalled the Americans that more than 100 abandoned the venture, severely weakening the leadership of the Army (Webb 1952:750). 
This page has been

redacted because it

contains restricted

information. 


\section{SITE OF THE BATTLE OF ROSILLO}

The reports of the location of the Battle of Rosillo are fragmented and contradictory. All reports of the battle prior to 1847 place it on Salado Creek, and it was not until after the Dawson Massacre in 1842, which did occur on Salado Creek far to the north, that the 1813 site became known as the "Battle of the Rosillo."

The first official report of the battle was in a proclamation issued April 22, 1813, by the victorious "Republican Army of the North," from Gutiérrez de Lara (1813a):

Finally, the battle of Salado, on 29 March. A memorable day for two generations to come. Does it not give you pause to see the complete defeat of nine-hundred and fifty well armed men, with six pieces of artillery which they handled speedily and adeptly? Ask those who scattered, and who have since reappeared around those parts, and you will be informed of the valor of those heroes, not daunted by either cannon or artillery fire.

Eleven days earlier, Gutiérrez (1813b) had written secretly to William Shaler, official agent to President Madison, to inform him of the battle:

On the 29th of the same month, when about 110 miles N. W. of La Bahia, one of our flank guards were attacked by a huge detachment of the enemy. We took a favorable position on a country plain where borders were thickly timbered. $20 \& 5$ rods of us, lay the whole force of the enemy.

On May 7 of the same year, John Sibley, Indian agent for the Orleans territory, reported to the United States Secretary of War (Garrett 1946:425):

On the 29th [Gutiérrez] was met about Eight Miles from St. Antonio by General Herrera with Twelve hundred Men \& Six Pieces of Cannon, a Battle Ensued which Continued about an hour. Good part of the time with Bayonets \& Swords in hand the two Armies all Mingled together the Result was Herrera was Compleatly [sic] defeated with the lost of all his Cannon \& much Baggage \& about one hundred Dead on the field of battle, \& Got Back to St Antonio in the greatest disorder.

On June 7, 1813, Bart Fleming (1813) in a letter to Levin Wailes, registrar of the Louisiana Land Office, described the action in this manner:

On the 18th March they left Labadia [sic] for San Antonia [sic] with an armed force of about 600 effective men and marched on within about five leagues of that place when their flanking party was fired on by the enemy in a large beautiful plain selected by them for the battle ground - there being no other manner of bearing on them than to charge as they had 6 pieces of cannon.

In 1841, Henry Stuart Foote (1841:188) described the action in this manner:

The Spanish army had no sooner commenced retrograding than a vigorous pursuit was initiated by the Americans, who overtaking the army of Salcedo, at Salado Creek, about nine miles from the capital, rushed upon it fiercely and defeated it at once with astonishing slaughter.

William Kennedy (1841:278), in his history of Texas, placed the scene of the action in this manner:

The royalists continued their march until they reached the Salado creek, where they waited in ambuscade for the Americans, who were now on the advance. On the 29th of March, having vainly tried to effect a surprise, the royalists were obliged to hazard an encounter on an open and beautiful plain. 
In about 1847, John Villars, a participant in the battle, corresponded with Mirabeau Buonaparte Lamar (Smither 1927:151):

Herrera stopped [at] a stream called Rosio [sic], occupying the water. Kemper advanced, the forces met and the fight was opened by a personal conflict between Ross and a Col. Montero; the latter seemed to banter Ross for a fight; Ross advanced and they slashed away at each other with their sabres, and in their furious charge upon each other, as Montero's horse passed the other Montero was shot down. The general action now commenced; it was brief but verry [sic] bloody; and resulted in the total flight of the Spanish force, and the capture of all their arms, ammunition and numerous cavayard [sic].

Also in The Papers of Mirabeau Buonaparte Lamar (Smither 1927:6) is a report dated December 1, 1853, in which the author is listed as anonymous, but from the information included within the report it is clear that it was written by José Antonio Navarro, a participant in the battle and later a signer of the Texas Declaration of Independence. He recalls the events in this manner (Gulick and Allen 1924:6):

Salcedo had scarcely reached San Antonio with his army, ere he was compelled to abandon it by order of Don Simon Hierra [sic], who met the Patriot army (if it deserve that name) consisting of nine hundred men under Gutiérrez on the Salado, at a point called Rosillo.

Yoakum (1855:166), in his History of Texas, presents a much more detailed account:

The American left was protected by the San Antonio river, along the bank of which they marched. About nine miles from San Antonio there was a ridge, of gentle slope, dividing the waters of the San Antonio, from the Salado. The side of this ridge next to the San Antonio, from the crest to the road, consisted of prairie; the side bordering the Salado was covered with chaparral, a species of thick underwood. In this chapparal the Spaniards were lying in ambush.

Colonel Warren D. C. Hall (1861:72), who participated in the battle under command of Kemper, described the setting in an article published in the 1861 Texas Almanac:

It was not long after Salcedo's arrival in San Antonio before he heard of the approach of the Americans, when Gen. Herrera immediately marched out the royal army to meet them, and took up a position below the Salado on the road leading directly from Labahia [sic] to San Antonio. The American army however took the left hand road by way of the Missions of Espada and Concepcion. The enemy were posted not far above the forks of the two roads, and the first information the Americans had of the enemy was given by their right flank being fired on by a picket from the royal army.

Sidney Lanier (1890:78), in his colorful history of San Antonio written in 1872, recounted the events in this manner:

Marching along the banks of the San Antonio river, with the left flank protected by the stream, this motley army arrived within nine miles of San Antonio, when the riflemen on the right suddenly discovered the enemy ambushed in the chaparrel [sic] on the side of a ridge.

The City Directory (1877-1878:11) of 1877-1878 reports the action in a history of San Antonio:

They [Royalists] sent out all of their advance force to a thicket on the Rosillo creek, nine miles below the town. They had a park of artillery; but the Republicans, anticipating an attack, marched in order of battle and when the Royalists opened fire upon them, returned it so effectively, and charged so vigorously upon the thicket, that the Spanish soon left the field and retreated in disorder to the city.... In history this is known as the battle of Rosalis, or Rosalio [sic], and there is great confusion among writers as to the place and the particulars of the fight. 
The City Directory (1879-1880:14) for the following year provided this version:

The Spanish army consisted of fifteen hundred regulars and one thousand volunteers, and they lay in ambush of the Rosalio [sic] creek, about nine miles from San Antonio.... The American or Republican army, anticipating an attack, marched in order of battle, and the riflemen discovering the ambush of the enemy fired upon them, when they immediately showed themselves on the crest of the hill, about four hundred feet above the Republicans.

Dudley G. Wooten (1898:81), in A Comprehensive History of Texas, 1685 to 1897, reprinted the text of Yoakum (1855), but added the footnote: "Known as the battle of Rosillo. Its exact locality is not known."

Antonio Menchaca (1937:15), who distinguished himself during the battle, in his Memoirs, written sometime prior to his death in 1879 and first published in 1907, related this version of the encounter:

The Americans gave them time to arive [sic] at S. A. when they advanced and encamped on the Rosillo. The Mexicans went from S. A. and a fierce batle [sic] ensued in which the Americans were victorious, killing about 200 Spanish soldiers and a great many wounded. The Mexicans retreated in a bad condition; the Americans remained on the field.

More recent historical publications of the battle are even less specific about its location. Garrett (1939:177) places the battle ". . . five leagues [15 miles] from the city ... on a wooded slope." Warren (1943:48) states, "No opposition was met with until the invaders had arrived within eight miles of San Antonio. Then, at a place near the Rosillo, Herrera's army of twelve hundred men attacked in full force on March 29."

Castañeda (1950:96) gives a more detailed report of the events:

On March 29, as they approached a thickly wooded area near the Salado River, some six or eight miles from San Antonio, Gutiérrez' army came upon a strong Royalist position. Salcedo and Herrera had decided to meet the enemy at a spot called "El Rosillo" in one last effort to check its advance.

Almaráz (1971:168) seems to concur that the battle occurred as “ . . . the filibusters approached Salado Creek, approximately three leagues [nine miles] south-east of the city of Béxar...." The latest book of this period is by Schwarz (1985:29), who places the battle “... on the east side of Salado creek about five leagues from Béxar, the Republicans were marching on the lower or Mission road...."

\section{SITE OF THE EXECUTIONS}

While the information of the battle site is scant, the site of the executions of the Spanish prisoners is even less specific, contradictory, and often patently in error. The early lists of victims are reasonably consistent but show considerable variance in later years.

The first official report of the executions was recorded in the statement by Guillermo Navarro, aide to General Herrera, given to 2nd Lt. José Antonio Benavides, of Company Three, Nuevo Santander, in Laredo on April 8, 1813. He testified to his observations prior to his escape from San Antonio (Gutiérrez 1813c):

It was evident that Antonio Delgado, corporal from the troops at Bexar and (one word unintelligible) of the Alamo Company was in charge of this party. The party had a number of saddled horses with them, and they ordered the Governors and other officials to mount them. Included were Don Simón Herrera, Don Manuel Salcedo, Don Geronimo Herrera, Don Miguel de Arcos and his two sons, Don José de Goecaechea, Don Joaquin de Ugarte, Don Juan Ignacio de Arrambide, Don José Amador, and the artilleryman, Don Antonio López. Also, a Captain of the artillery group from Nueva Vizcaya. As soon as all of them had mounted, the party left for the place called La Tablita. About 9:00 a.m. of the following day, the aforementioned group [renegades] returned, bringing back the horses on which the Governors 
and other officials had been mounted. They were also carrying a number of personal items of apparel that were recognized by the respective assistants as having belonged to their Lordships the Governors.

The executions were reported by Gutiérrez (1813b) to Shaler in a secret letter dated April 11, 1813:

Such the [one word illegible] heretofore complained of by the Creoles in former revolutions of this kind, an such the unheard of inhumanity exercised toward them, at their disposal, Salcedo, Herrara [sic] and 12 more intact officers are now no more. They have fallen by the hands of their own subjects, who best knew them.

John Sibley, in his report to the Secretary of War on May 7, gave this account (Garrett 1946:425):

they were Accordingly Marched Out under a guard of Spaniards, \& taken about Six Miles to a Creek, where they were all put to Death. Among them were Governor Salcedo, General Herrera \& his Brother the Major, Captain Arcos, a Very Rich Inhabitant of St. Antonio \& his two Sons, Captain Domingus [sic], late Inspector Genl., Capt Ugart [sic], late Commander at Nacogdoches. The others I do not know personally but were from beyond River Grand. . . The Spanish officer who had the Charge of those Prisoners justified himself. That Salcedo had Caused his Father \& two Brothers to be beheaded in St Antonio, their heads Draged [sic] by Mules to Montclova \& through the Streets of that City, \& Several other Similar Acts.

Bart Fleming (1813) reported the incident in this manner:

Genl Don Bernardo the old woman had the officers beheaded or rather tied up to a tree and their throats cut like killing sheep. This was purposely concealed from the Americans as he told them he intended to send them to the nearest port to ship them to their own country - when about five leagues from the army - they tied them up \& cut throats.

After General Joaquin de Arredondo defeated the Republican Army at the Battle of Medina, August 18, 1813, he had the bodies retrieved and interred in San Fernando Cathedral on August 28. The official list of the church indicates the following burials (San Fernando Cathedral Burial Records 1808-1860):

Amador, Gregorio, Spanish Lt.

Arcos, Francisco de, Spanish 2 Lt.

Arcos, Luis de, Spanish Lt.

Arcos, Miguel de, Spanish Lt. Col.

Arrambide, Juan Ignacio, Spanish Capt.

Caso, Juan, Spanish Lt.

Goecaechea, Jose, Spanish Lt. Col.

Herrera, Geronimo de, Spanish Col.

Herrera, Simon de, Spanish General of the Eastern Providence

López, Antonio, Spanish Lt.

Pereira, Francisco, Spanish retired Capt.

Salcedo, Manuel de, Spanish Governor of this Capital

Ugarte, Joaquin de, Capt.

Echeverria, Juan, Spanish Capt.

William Kennedy (1841:280), in his 1841 history of Texas, wrote this account:

Deception was resorted to for the accomplishment of a deed worthy of assassins. Under the pretence of sending the condemned to Matagorda, for the purpose of being shipped to Spain, the fourteen Spanish chiefs were removed from Bexar, and, when on the way, were conveyed to the cover of a convenient wood, from which they never emerged. The waters of a brook flowing red with blood revealed the story of their fate. 
Foote (1841:188) states: "There were, among the numerous prisoners in the hands of the Americans, seventeen Spanish officers, all of whom were caused by Bernardo to be butchered in cold blood, in accordance with the inhuman usages then, as at present, prevailing throughout the Mexican provinces." Curiously, he included ex-Governor Manuel Antonio Cordéro y Bustamante among the victims, yet Cordéro was governor of Coahuila until 1817 (Webb 1952:412).

Villars, in ca. 1847, recounted that “. . . by stealth, without the Americans knowing it, and ordered them 14 in number to be taken to the Rosillo where the last fight had been, and have their throats cut" (Smither 1927:15). This is the only account to place the event on Rosillo Creek.

José Antonio Navarro, in his record of the event, gave us this graphic account (Gulick and Allen 1924:7):

On the night of the second, or, it may be on the fifth of April, a party of sixty Mexicans in command of Capt. Antonio Delgado took from San Antonio, the fourteen Spanish victims including four of Mexican origin. Arriving on the east side of the Salado near the spot where the battle of Rosillo had been fought, they hastily dismounted from their horses and with no other weapon, save their blunt knives, which these monsters carried in their girdles for camp use, they cut the throats of their prisoners, previously heaping upon them the most insulting expressions and outrageous epithets. Some of these assassins, with brutal irony whetted their knives upon the sole of their shoes in the presence of their bound victims.

Navarro also included a list of the victims (Gulick and Allen 1924:8):

\section{Spanish}

Manuel de Salcedo

Simon de Herrera

Geronimo Herrera

Juan de Echeverria

José Mateos

José Goecaechea

Juan Ignacio Arrambide

Gregorio Amado

Antonio Lopez

Mexican

Miguel de Arcos

Louis de Arcos

Francisco de Arcos

Juan Caso

Yoakum (1855:169) stated, “... they were taken about a mile and half below the town, to the point of a small ridge that runs down to the river; and there, on the east bank of the stream, the prisoners were stripped and tied, and their throats cut!" From Yoakum's footnotes, it is obvious that he had access to Navarro's report, for he cites several passages from Navarro's report and also includes the list of victims as previously given.

An account given in the Texas Almanac by Colonel Warren D. C. Hall (1861:73), states that:

... the officers were accordingly delivered up to Delgado, who then immediately took them to the battleground of Salado, where he had their throats cut in the most horrible manner; and their bodies, it was said, were thrown into the river. There was but one exception to this savage butchery, and this one was shot in compliance with his earnest entreaties.

Sidney Lanier (1890:79), also used the Navarro account of the execution, but his list of the victims included ex-Governor Cordéro. He places the site as "a mile and a half from town . . . on the bank of the river...." 
John Henry Brown (1893:59) wrote in his book, The History of Texas from 1685 to 1892:

On the 7th occured [sic] the atrocious butchery of fourteen Spanish officers, including Salcedo, Herrera, and Cordero, by order of Gutierrez de Lara. . . . They were delivered up to Juan Delgado and taken to the battleground of Salado, where with one exception, their throats were cut and their bodies thrown into the river.

Beltran, in his autobiography written sometime prior to his death in 1897 , gave an extremely detailed narrative. At the time of the battle, he was a prisoner of the Royalist and held captive in the Alamo. He gives us some insight into the actions of Delgado (Hunter 1925:45):

In this command was a company commanded by Captain Antonio Delgado, a son of the Colonel Delgado who was executed by Salcado [sic], and whose head was still exposed on a pole at the Alamo crossing. When Captain Delgado saw this gruesome relic of the doting father, he burst into a fit of weeping, which soon changed to a parozysm [sic] of uncontrolable [sic] fury.

His narrative of the event is extremely detailed (Hunter 1925:48-49):

Ten Spaniards and five Mexicans rode away from the Alamo that fatal morning to an ignoble death. General Simon de Herrera, Ex-Governor Cordero, Governor Manuel de Salcedo, Lieutenant Colonel Herrera, Captain Jose Mateos, Juan Ignacio Arabido, Francisco Pereira and Gregorio Amado - these were Spaniards. The following were Mexicans; Antonio Lopez and Lieutenant Juan Caso, Lopez was not connected with the army in any way, and his offending was in connection with the betrayal and arrest of Colonel Delgado. A few miles below the city the escort halted on a small creek that flowed into the San Antonio River. Here the prisoners were untied and dismounted, one at a time, and each man was tied to a tree, hand and feet. Realizing that their end was near, these unhappy men begged to be spared until a priest might be brought from town to administer the last rites of the church, but this was refused. 'You sent my father into eternity, denying him the consolation of religion in his last extremity,' said Delgado, addressing Salcedo. Ex-Governor Cordero was the third man to be led to the fatal tree. Before his arms were pinioned about the tree he called on Lieutenant Santos to him and, handing his watch and a ring, asked him to convey these articles to Dr. Orramel Johnson, with the request that he forward them, if ever opportunity presented, to some one in the City of Mexico - wife, mother or relatives - I have forgotten which.

When the fifteenth prisoner was securely bound to a tree, deliberate preparations were made for the shocking tragedy. Herrera exhorted his companions in misfortune to face the ordeal like men and to die like true soldiers, loyal, even in death, to their masters, the King. Seeing their long, keen knives in preparation for the carnival of blood, Lieutenant Herrera, a mere youth, warned Delgado of the day of signal retribution and defied him to do his worst.

Manuel Salcedo begged to be permitted to die like a soldier. He ask to be shot, and for reasons that probably will never be known, his request was granted. He was the first to be executed, and then at a signal given by Delgado, the men chosen for the murderous task advanced and, with gleaming knives, cut the throats of the remaining fourteen.

The bodies of these victims were unleashed and thrown into the creek. Delgado and his men remained near the scene of the heinous crime throughout the remainder of the day, and late at night returned to the city.

In Menchaca's (1937:15) Memoirs is this account of the affair:

At 3 o'clock of the same day the Americans imprisoned Miguel Delgado, Santiago Menchaca, Francisco Riojas, and twenty-one others of the American side, and Manuel Salcedo, Simon de Herrera, Geronimo Herrera, Francisco Povela, Miguel de Arcos, and old Capt. Graviel de Arcos, son of Capt. de Arcos, Miguel de Arcos, Jr., Miguel Pando, Juan Francisco Caso, and 
four others, of Mexican side were all taken to the Salado, and arrived at the Rosillo the same evening and that same evening were beheaded....

Garrett (1939:180), in his 1939 account of the event, places the execution site as “. . . six miles from the city. ..." Warren (1943:50) places the site ". . about a mile and a half below the town, to the point of a small ridge that runs down to the river. ..." Oddly, he includes Nemesio de Salcedo y Salcedo, Manual's uncle and superior, among the victims.

Carlos Castañeda (1950:99) reports the executions in a rather different manner:

Late that evening, however, a group of one hundred armed men, commanded by Antonio Delgado and Pedro Prado, forcibly took charge of the prisoners and marched them out by the south road, which leads to La Bahía. After proceeding a short distance to a site called ' $\mathrm{La}$ Tablita,' described as a small ridge that runs down to the river and variously estimated as from two to six miles from the city....

The opinion has been generally held, too, that fourteen prisoners were executed. The list of the men put to death, however, names seventeen: Govenor Manuel Salcedo, Colonel Simon Herrera, Captain Miguel Arcos, who figured in the counterrevolution of Colonel Zambrano; Captains Juan Ignacio Arrambide, Bernardino Montero, of Nacogdoches, Francisco Pereira, and José Amador; Lieutenants Juan Cantu, Juan Caso, N. Musquiz; Ensign N. Rodríguez, Francisco Arcos, N. Parras; and Sergeants Juan Bautista Solís, Luís Arcos, and Miguel Prado.

Castañeda cites as a source for his list Garza's, Dos Hermanos Heroes, which he states is based on the papers of Gutiérrez.

Almaráz (1971:171) places the execution site as “... a southeasterly direction toward Salado Creek ... where the battle of Rosillo occurred. ..." Finally, Schwarz (1985:31) has the execution site "... six miles from Béxar, near the recent battle site."

\section{EPILOGUE}

The cruelty of the executions of the Spanish prisoners caused many Americans to abandon the adventure. Samuel Kemper led more than 100 of his troop back to Louisiana. The following June, Colonel Ignacio Elizondo laid siege to San Antonio with about 900 men. Reuben Ross, Kemper's successor, advised a retreat, but when a council of war refused to support him, he resigned and was replaced by Henry Perry. At the Battle of the Alazán, June 20, 1813, Perry defeated Elizondo and scattered his force.

In an intrigue contrived by Shaler, Gutiérrez was relieved of command and replaced by José Alvarez de Toledo. Toledo arrived in San Antonio on August 1, 1813 (Webb 1952:750). On August 18, in a battle near the Medina River, his demoralized army met the combined forces of Elizondo and General Joaquín Arredondo and were severely beaten.

Arredondo's vengeance was swift and cruel. In addition to the 600 slain on the field of battle, he imprisoned most of the population of the city. At least 60 prisoners were shot in the public plaza (Schwarz 1985:109). To testify to the horror of the situation, seven months later, on March 9, 1814, Father José Darío Zambrano, the priest at San Fernando Cathedral, wrote to the governor requesting permission to bury the "corpses which are placed in the plaza" (San Fernando Cathedral Burial Records 1814).

\section{SURVEY RESULTS}

A pedestrian survey utilizing a VLF-TR metal detector was conducted March 24, 1988. The team consisted of the author, two staff (CAR-UTSA) assistants, and three volunteers from the Southern Texas Archaeological Association. The survey area consisted of a plowed, cultivated field at the corner of South 
This page has been

redacted because it

contains restricted

information. 


\section{CONCLUSIONS AND RECOMMENDATIONS}

A careful study of the historical sources now available on the encounter of the Spanish Army and the "Republican Army of the North" fails to reveal an exact location for the battleground. Estimates of distance from San Antonio range from five to fifteen miles, with nine miles appearing most often. Traditional measures of distance from the city during the Spanish period originate from the dome of San Fernando Cathedral.

All reports place the battleground near either Salado Creek or Rosillo Creek, or both. The one consistent historical fact common to all the reports is that both armies were progressing by way of the road to La Bahía. That road was, and still is, the old Goliad-Corpus Christi Road. On the 1858 plat of the Juan Joseph Montez de Oca grant (Fig. 3), the road crosses Salado Creek at the pass below its confluence with Rosillo Creek above the "Rincon de la Candelaria" (GLO 1778; Survey Book of Bexar County 1858:113). Testimony to the Bexar County Commissioners Court attests to the fact that "the old Goliad road is the oldest in the state east of the San Antonio River," with one witness dating it as early as 1740 (Old Goliad Road 1890-1891). South W. W. White Road and Hildebrandt Road did not exist at the time of the 1858 plat. This intersection is, in fact, the northeast corner survey lines of the grant. Thus, it would appear that the most probable location for the battlefield is some 1.9 miles from the historical marker on the banks of the Salado Creek below the confluence of the Salado and Rosillo Creeks (Fig. 1).

The site of the executions can only be determined with less certainty. While most accounts place the execution at or near the battlefield, others place it on different streams, and some place it within a mile and a half of the city. As to the list of victims, the church records would appear to be the most accurate. Jose Antonio Navarro's list also seems to comply, with the exception of the name Francisco Pereira and the absence of the name José Mateos.

Since the bulk of the evidence seems to support the fact that the historical marker is in error by almost two miles, any alteration to the area will not affect the battlefield in any manner. There is no evidence that the project area has any historical significance. In addition, the project area has either been totally excavated or severely altered. Therefore, no further work is recommended, and future use of the project area would have no impact on any prehistoric or historic resources. 


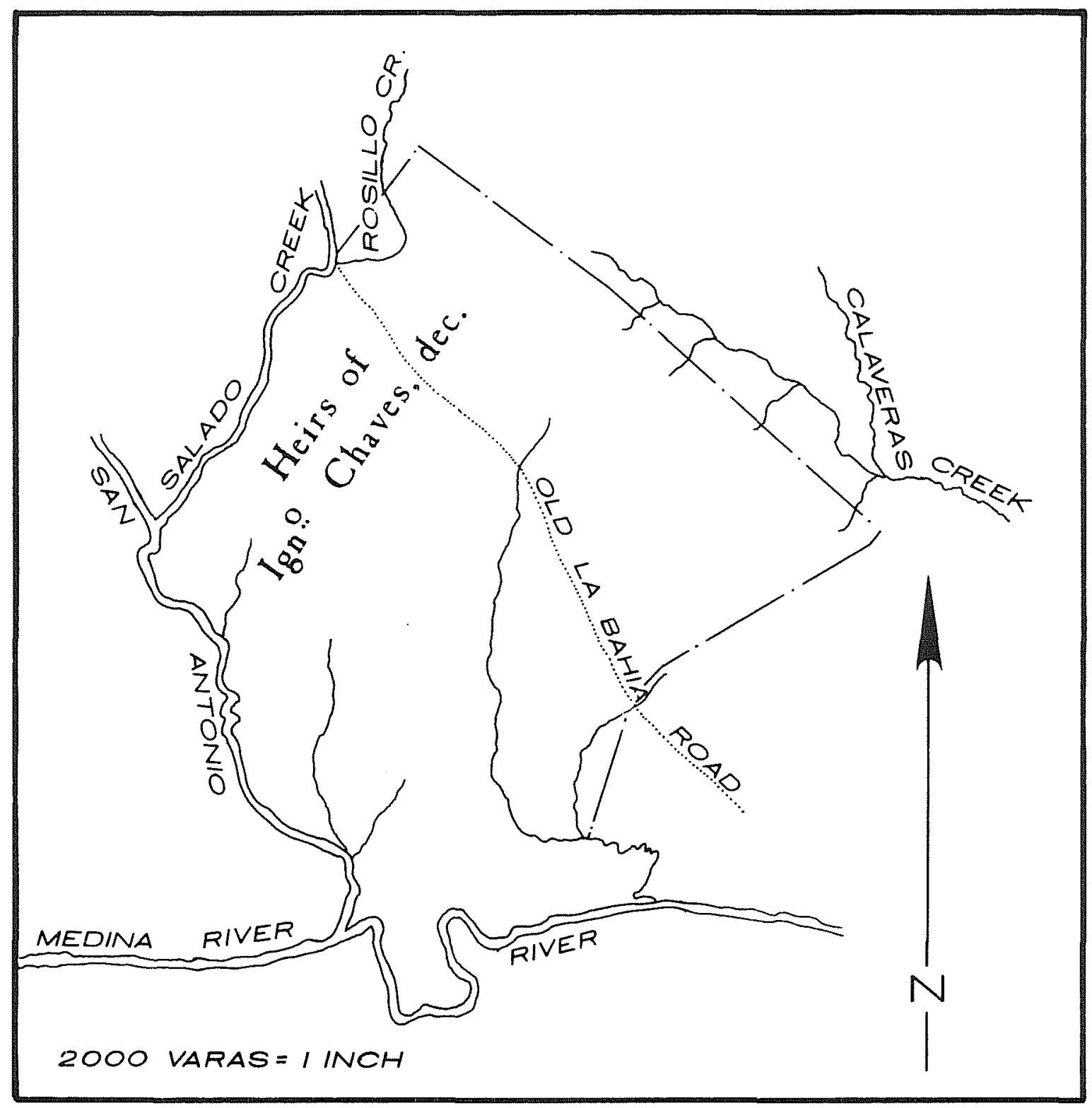

Figure 3. Original Grant Plat. Montez de Oca Grant, adapted from the plat by F. Giraud, Bexar District surveyor, dated May 14, 1858. 


\section{REFERENCES CITED}

Almaráz, F. D., Jr.

1971 Tragic Cavalier, Governor Manuel Salcedo of Texas, 1808-1813. University of Texas Press, Austin, Texas.

Brown, J. H.

1893 History of Texas from 1685 to 1892. Volume I. 1970 facsimile, Jenkins Publishing Company, Austin, Texas.

Butler, B.

1974 Letter to Anne A. Fox reporting the results of skeletal analysis of Blue Wing Road burial, January 18. On file at the Center for Archaeological Research, The University of Texas at San Antonio.

Castañeda, C. E.

1950 Our Catholic Heritage in Texas, The Fight for Freedom, 1810-1836. Volume VI. Von Boeckmann-Jones Company, Austin, Texas.

City Directory

1877- Moody and Morrison's Directory of the City of San Antonio. Galveston, Texas.

1878

1879- Morrison and Fourmy's General Directory of the City of San Antonio. Marshall, Texas.

1880

Dooley, C. and B. Dooley

1985 Why Stop? A Guide to Texas Historical Roadside Markers. 2nd edition. Gulf Publishing Company, Houston, Texas.

Fleming, B.

1813 Letter from Bart Fleming to Levin Wailes, Esq. June 7. Gutiérrez de Lara collection, Eugene C. Barker Texas History Center, The University of Texas at Austin.

Foote, H. S.

1841 Texas and the Texans, or Advance of the Anglo-Americans to the Southwest. Volume I. 1935 facsimile, The Steck Company, Austin, Texas.

Fox, D. E.

1983 Traces of Texas History, Archeological Evidence of the Past 450 Years. Corona Publishing Company, San Antonio, Texas.

Garrett, J. K.

1939 Green Flag Over Texas, A Story of the Last Years of Spain in Texas. Cordova Press, Inc., New York and Dallas. 
Garrett, J. K. (continued)

1946 Dr. John Sibley and the Louisiana-Texas Frontier, 1803-1814. The Southwestern Historical Quarterly XLIX:Letter 38. The Texas State Historical Association, Austin, Texas.

General Land Office (GLO)

1778 Montez de Oca File. Archives and Records Division, Stephen F. Austin Building, Austin, Texas.

Gulick, C. A., Jr. and W. Allen

1924 The Papers of Mirabeau Buonaparte Lamar. Volume IV. Von Boeckmann-Jones Company, Austin, Texas.

Gutiérrez de Lara, J. B. M.

1813a Proclamation. Gutiérrez de Lara collection, Eugene C. Barker Texas History Center, The University of Texas at Austin.

1813b Letter from Gutiérrez to William Shaler, Esq. Gutiérrez de Lara collection, Eugene C. Barker Texas History Center, The University of Texas at Austin.

1813c Deposition of Guillermo Navarro, April 8, 1813. Translation by Dora Guerra (see appendix to this report). Gutiérrez de Lara collection, Eugene C. Barker Texas History Center, The University of Texas at Austin.

Hall, W. D. C.

1861 Revolution of Texas in 1812. In the Texas Almanac. Richardson Publication Company, Galveston, Texas.

Hunter, J. W.

1925 San Antonio's First Great Tragedy. Frontier Times 3(1), October. Bandera, Texas.

Kennedy, W.

1841 Texas: The Rise, Progress, and Prospects of the Republic of Texas. Volume I. R. Hastings, London.

Lanier, S.

1890 San Antonio de Bexar. In San Antonio de Bexar, A Guide and History, by W. Corner:68-94. Bainbridge and Corner, San Antonio, Texas.

Menchaca, A.

1937 Memoirs. Yanaguana Society Publications II, San Antonio, Texas.

Old Goliad Road

1890- Folder G. Bexar County Archives, Office of the County Clerk, Bexar County Courthouse, 1891 San Antonio, Texas. 
San Fernando Cathedral Burial Records

1808- Microfilm, entry 541. John Ogden Leal, translator. Office of the County Clerk, Bexar 1860 County Courthouse, San Antonio, Texas.

Schwarz, T.

1985 Forgotten Battlefield of the First Texas Revolution, The Battle of Medina, August 18, 1813. Robert H. Thonhoff, editor. Eakin Press, Austin, Texas.

Smither, $H$.

1927 The Papers of Mirabeau Buonaparte Lamar. Volume IV, Part 2. Von Boeckmann-Jones Company, Austin, Texas.

Survey Book of Bexar County

1858 Volume F1. Bexar County Archives, Office of the County Clerk, Bexar County Courthouse, San Antonio, Texas.

Warren, H. G.

1943 The Sword Was Their Passport, A History of American Filibustering in the Mexican Revolution. Kennikat Press, Port Washington, New York.

Webb, W. P.

1952 The Handbook of Texas. Volume I. The Texas State Historical Association, Austin, Texas.

Wooten, D. G.

1898 A Comprehensive History of Texas, 1685 to 1897. Volume I. William G. Scaff, Dallas, Texas.

Yoakum, $\mathrm{H}$.

1855 History of Texas from its First Settlement in 1685 to its Annexation to the United States in 1846. Volume I. 1935 facsimile, The Steck Company, Austin, Texas. 


\title{
APPENDIX \\ TRANSLATIONS FROM THE SPANISH PERIOD, 1813-1814
}

\author{
Dora Guerra
}

\section{INTRODUCTION}

Translation of any language, for any time period, for any use, is a precise science. A translator must, to the best of his ability, be able to convey to present-day readers, past events expressed in styles long out of use. The act goes beyond knowing what words mean, and then stringing them together across a page. It involves familiarity with usage of language, with a historical period, its events, and the personae dramatis. Words, after all, do not appear on a page by osmosis. They were placed there by a writer from a distant past who was feeling something about what he was writing. That writer's particular choice of words, chosen consciously or unconsciously, carried with them a mood, a tone locked into place forever by word order, tense, syntax, and stress. It is to these that a translator must look, in order to extract the meaning and substance within a piece of writing.

There is a precise methodology that goes along with the skill. Deciphering handwriting aside, the translator who knows his own language well, and is equally familiar with the language he attempts to translate has an edge at maintaining fidelity to substance. There are myriad subtle distinctions to be made in dealing with the value of words, and each translator brings to that his own level of knowledge, sensitivity, and synchrony.

Three steps are involved. First, there is the reading of an original, which demands deciphering handwriting, hopefully accurately. Sense must be made out of lengthy, poorly constructed, arcane, unpunctuated accounts which often require more than one, two, or three readings, before immersion into the spirit of what is being said takes place. Second, there is the making of a transcription. A transcription is an exact duplication of the original handwritten piece. It must match the original word for word, line-ending by line-ending, and line by line, without any attempt to update, correct, add, or delete anything in the original. If a word, or a series of words are illegible, it must be stated within parentheses on the line and position where they appear, e.g., three words illegible. Guesswork, even at its instinctual best, is not acceptable, nor is it encouraged. The purpose of a transcription is to allow scholars to match the original against its transcription and ascertain its accuracy for themselves. A misinterpreted word or series of words could have dire consequences. Accuracy is always the objective. Having the transcription in the same word for word, line by line order facilitates the venture. Transcription also allows scholars who know the language but are unable to decipher the handwriting to obtain the needed information in legible typescript, and in the same format as the original. Format is important, and must be respected. The order and tone of words on a page have a story of their own to tell. Finally, there is the translation. There are two schools of thought with regard to translation. There is the one which renders a translation in language contemporary with the reader; and the one which uses the language of the original and translates it into language contemporary to it. Whatever the method, it is important to guard against paraphrasing, lest meaning be lost. Paraphrasing might be accurate and readable, but might sacrifice the fullness of a concept (see Haggard 1941). This translator attempts to adhere as closely as possible to the original style of the document, for the insight it sheds into the historical period under investigation. It is not the easiest avenue, because Spanish phrasing of the time is extremely convoluted, and becomes cluttered and cumbersome in translation; therefore, some modernization must take place. If it is possible to maintain the spirit of the original, this translator attempts to do so.

"The Field Survey and Archival Research for the Rosillo Creek Battleground Area, Southeast San Antonio, Texas" uncovered two types of original source materials with which this translator worked. One type consists of copies of documents in original handwriting (holograph; see burial accounts of Don Simón Herrera, Governor Salcedo, Group Burial, and request for Permission to Give Christian Burial). The other type consists of copies of previously transcribed documents (transcript; see Proclama, "Deposition of Guillermo Navarro, April 8, 1813," and "Deposition of Guillermo Saldaña, April 8, 1813"). In some cases, only a transcription of an original is available, and must therefore serve as "original." When a translator and transcriber are not the same person, 
a translator has no choice but to trust the accuracy of the unknown transcriber. The transcriber of the documents used for this project is unknown to the translator.

For clarity, continuity, and ease of use, the original source materials for this report have been organized in corresponding sets. Three sets consist of copies of the Spanish transcript, followed by its translation, and there are three burial records which have the Spanish holograph, followed by its transcription, followed by its translation. 
DEPOSITION OF GUILLERMO SALDAÑA, April 8, 1813 (Gutiérrez de Lara 1812-1813)

\section{Transcription for the Deposition of Guillermo Saldaña}

D. ${ }^{\mathbf{n}}$ Jose Antonio Venavides $1 .^{\text {er }}$ Alferez dela $3 .^{\mathbf{a}}$ Comp. ${ }^{\mathrm{a}}$ Volante del Nvo Sant. ${ }^{\text {er }}$ por dispocision del Teniente D Miguel Serrano, Comandante de dha. Comp. a y de las Armas de este puesto; Conforme á orn. de dho. Comand. ${ }^{\text {te }}$ en virtud delo acaesido p. ${ }^{\mathrm{r}}$ la Sub-blevacion de $S$. $^{\mathrm{n}}$ Fernando de Bexar he tomado la Siguiente Relacion al Mozo Guillermo Saldaña Sirvente del Teniente Coronel D. Juan Martin de Echabarria, cuyo Mozo se ha presentado en esta viniendo de Bexar, mandado p. ${ }^{\text {r }}$ su Ama con fin de pasar hasta la Villa de Hoyos á avisar dela novedad ocurrida a su hermano D. Ysidoro [sic] Barreda para q. ${ }^{\mathrm{e}}$ facilite venir a sacarla de Bexar $=$ Preg. $^{\text {do }}$ Que relacione y diga todo lo acaesido en dho. Bexar; Dixo: Que el dia $1 .^{\circ}$ de Abril de parte delos Americanos entro á Bexar uno de ellos con propocisiones de $\mathrm{q}^{\mathrm{e}}$ se rindieran los Gefes y Canton de Tropas q. ${ }^{\mathrm{e}}$ existen alli, y de lo Contrario dispondrian atacar a Bexar: consequente á esta propocision mandaron los Sres Governadores al Cap. ${ }^{\mathbf{n}} \mathrm{D}$ Nicolas Venites proponiendoles q. entraran sin disposicion de Guerra, y con este aviso se introdugeron a Bexar con todo su Campamento; y la prim. ${ }^{\mathrm{a}}$ provid. ${ }^{a} q^{e}$ tomaron fue intimar Arresto alos Sres Gov. $y$ en Seguida poner en livertad todos los Reos q. ${ }^{\text {e }}$ habia en la Carzel, y desarmar. ${ }^{\text {n }}$ ala poca Tropa auxiliar q. ${ }^{\mathrm{e}}$ habia quedado de Nvo. Reyno y Colonia, dejando con sus Armas e incorporados con ellos ala Comp. ${ }^{\mathrm{a}}$ Veterana, Milicianos y Vezin's de Bexar y lo mismo ala Comp. ${ }^{\mathrm{a}}$ del Alamo, y la Bahia; e igualm. ${ }^{\text {te }}$ desarmar. ${ }^{\text {n }}$ alos Oficiales y tropa q. ${ }^{\text {e }}$ habia queda-

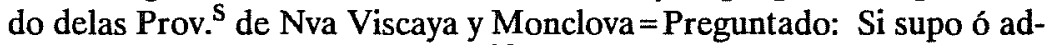
virtió q. ${ }^{\mathrm{e}}$ las citadas Tropas á q. ${ }^{\text {nes }}$ no desarmaron los Americanos,

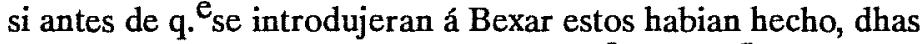
tropas alguna defenza: Dixo: Que nó, q. ${ }^{\mathrm{e}}$ antes $\mathrm{p}^{\mathrm{r}}{ }^{\text {el }}$ contrario de un dia antes dela introducion á Bexar, dhas. tropas y Milicia nos q. ${ }^{\mathrm{e}}$ no desarmaron y muchas Mugeres, se fueron ala Mision de Concepc ${ }^{\mathbf{n}}$ á incorporarse con los citados Americanos; y tambien [one word missing] se desia q. ${ }^{\mathrm{e}}$ como 300 Yndios de Nacodoches venian con dhos. [Ame]ricanos = Preguntado: Si tiene alguna otra cosa $q^{\mathrm{e}}$ relacionar de el particular, Dixo: Que no, $q .{ }^{\mathrm{e}}$ todo lo que ha relacionado es Verdad conforme se le ha preguntado = Villa de Laredo alas $8 \mathrm{del}$ mañana. del 6. de Abril de 1813.= Jose Antonio Venabides=Es copia ala letra dela Declaracion $q .{ }^{\mathrm{e}}$ acabo de resibir dirigida $\mathbf{p}{ }^{\mathrm{r}}$ el Teniente Comandante de Laredo D. Miguel Serrano=Monterrey alas dela Noche del dia 8. de Abril de 1813. = Bustamante =

Es Copia

Arrendondo (Rúbrica) 


\section{Translation for the Deposition of Guillermo Saldaña}

Don José Antonio Venavides [sic], 2nd Lt. in charge, Third Mobile

Company, Nuevo Santander. By order of Lt. Don Miguel Serrano, Commander

of said Company, and of the troops at this post; in conformance with

the order given by the aforementioned Commander, and in view of the

events caused by the insurrection at San Fernando de Bexar, the

following deposition was taken from the young man, Guillermo Saldaña,

servant of Lt. Col. Don Juan Martin Echabarría [sic]. Said young man

appeared in this town having come from Bexar. He was sent by his mistress

with instructions to go to the town of de Hoyos to inform her brother

Don Ysidro Barreda, of the occurrences at Bexar, and of his need

to make arrangements to assist her in her escape. [Saldaña] was urged to

relate what had transpired in Bexar. He said the following: On April 1,

an American [insurrectionist], from a group of many, came into Bexar

suggesting that the leaders and troops assigned to Bexar surrender, or if they refused, the [insurrectionists] would attack. In response to this

threat, their Excellencies, the Governors, sent Capt. Don Nicolás Venites

[sic] to tell them to enter the town in peace, rather than war. After

this message was delivered, they entered Bexar with all their military

forces. The first thing they did was to announce the arrest of their

Excellencies, the Governors. Immediately after, they freed all the

jailed criminals. They then disarmed the few remaining auxiliary troops

from the Nuevo Reyno y Colonia. The veteran Bexar militia as well as the

companies from the Alamo, and from La Bahia were allowed to keep their

firearms, and were incorporated into the ranks of the Americans. They

then proceeded to disarm the remaining officers and troops from the

Province of Nueva Vizcaya and Monclova. Asked if any attempt at defense

had been made by those troops who had been allowed to keep their firearms,

Saldaña explained that on the contrary, a number of those troops and

militia, as well as a large number of the town's women left to join the

Americans at Mission Concepción, the day before the Americans entered

Bexar. It was also rumored that there were about three hundred Indians

from Nacogdoches lined up with the Americans. When asked if he had any

more to add, the young man said no. He said that all of his statements and answers to all the questions asked were true.

Laredo,

José Antonio Venavides [sic]

8:00 a.m.

6 April 1813

This is a verbatim copy of the declaration which I have just taken, and

which was overseen by Lt. Commander of Laredo, Don Miguel Serrano.

Monterrey, ? p.m.

Bustamante

8 April 1813

\section{COPY}

Arrendondo

(Rubric) 


\section{Transcription for the Deposition of Guillermo Navarro}

El 1. ${ }^{\text {er }}$ Alferez dela 3. ${ }^{\text {a }}$ Comp. ${ }^{\text {a }}$ Volante del Nvo Santander D. Jose Antonio Venavides, por dispocision del Teniente D. Miguel Serrano Comand. $^{\text {te }}$ de dha Comp ${ }^{\mathrm{a}}$ y de las Armas de este puesto, en virtud delo acaecido en Bexar ha tomado la Sig. ${ }^{\text {te }}$ relacion al Soldado Veterano Guillermo Nabarro, de la Comp. ${ }^{a}$ de Lampazos, asistente del Teniente Coronel D. Geronimo de Herrera, cuyo Sold.se ha presentado en esta alas 12 del dia 8 de abril de 813 [sic]. habiendo salido de Bexar el 5 del Corriente á las 4 dela tarde=Prevenidole: Relacione todo lo $\mathrm{q}^{\mathrm{e}}$ Sepa y halla advertido delo susedido en Bexar, dijo, $\mathrm{q}^{\mathrm{e}}$ el dia 3 del presente al anocheser vió montada a cavallo una partida de hombres en num. ${ }^{\circ}$ como de ciento de Americanos y tropas dela Bahia, Alamo y Bexar, y q. ${ }^{\mathrm{e}}$ se reconocia entre ellos con mando en dha tropa a Antonio Delgado, cavo delas Milicias de Bexar, y prado de la Comp. ${ }^{\mathrm{a}}$ del Alamo, cuya citada tropa trageron Cav. $\mathbf{s}$ ensillados é hicieron montar áa Cab. ${ }^{\circ}$ alos Sres Governadores y demas Jes y of. ${ }^{\mathrm{S}} \mathrm{q}^{\mathrm{e}}$ sigue esta relacion: D Simon de Herrera: D. Manuel Salcedo: D. Geronimo Herrera: D. Mig ${ }^{1}$ de Arcos y sus dos hijos, D. Jose de Goecaechea: D. Joaquin de Vgarte: D. Juan Ygnacio de Arrambide: D. Jose Amador y al Artillero D. Antonio Lopez y á otro Cap. ${ }^{\mathbf{n}}$ Artillero de los de Nva Viscaya, y concluido q. ${ }^{\mathrm{e}}$ montaron á Caballo se marchó dha. Comitiba p. ${ }^{\mathrm{a}}$ el parage dela Tablita, y al dia sig. ${ }^{\text {te }}$ como alas 9. dela mañana bolbio la referida partida de tropa, trayendo los Cav. ${ }^{\mathrm{s}}$ en q. ${ }^{\mathrm{e}}$ sacaron alos Sres Governador $s$ y demas oficiales, trayendo varias prendas delas $\mathrm{q}^{\mathrm{e}}$ llebaron en su Bestuario los Sres Governad, ${ }^{\mathrm{s}}$ que las conocieron sus asistentes: Dise tambien $\mathrm{q}^{\mathrm{e}}$ tienen pricioneros a $\mathrm{D}$.

Jayme Gurza [sic]: D. Antonio Vilano: al Teniente Ramires, al Alferes Padilla: Al Capitan D. Luis Galban y otros varios q. ${ }^{\mathrm{e}}$ ignora sus nom

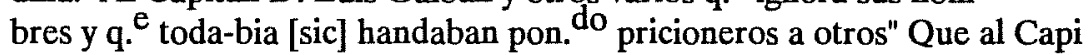
tan Charles y Teniente Saldana le pasó aviso D. Gaspar Flores de q. ${ }^{e}$ se saliesen lo mas pronto que pudieran $p .{ }^{r}$ q. ${ }^{e}$ trataban de ponerlos pricioneros: Dice q. ${ }^{\mathrm{e}}$ a toda la tropa que habian desarmado ant. como ya se ha dado parte, $q .{ }^{\mathrm{e}}$ la formaron y les propucieron $q .{ }^{\mathrm{e}} \mathrm{si}$ querian seguir su partido se les devolberian sus Armas: Dise q. muchos admitieron; $\mathrm{p} .{ }^{\circ} \mathrm{q} .{ }^{\mathrm{e}}$ advirtió q. ${ }^{\mathrm{e}}$ entre ellos habia muchos q. se inclinaban a venirse con sus Arm. ${ }^{\mathrm{S}}$ Dise que acepcion delas Tropas del Alamo Bexar y Bahia, sigun [sic] los trozos se formaban, de Americanos reguló sean como 700 y a mas alg. ${ }^{\mathbf{n}}$ num. ${ }^{\circ}$ de Yndios de adentro y muchos Lipanes: Dise q. ${ }^{\mathrm{e}}$ han saqueado las Casas de Europeos y Criollos, y lo mismo destrosaron los Ganados mayores y menor: Dise que oyó decir entre ellos q. ${ }^{\mathrm{e}}$ en el term. ${ }^{0}$ de 3 . meses se pasaban al presidio de Riogrande con fin de pasar adelante, y q. ${ }^{\mathrm{e}}$ si [sic] les oyo decir se reselavan de llegar a Monclova=Preg: ${ }^{\text {do }}$ si tiene otra cosa que decir sobre el particular: Dixo: Que no: que quanto ha dho es la verdad segun se le ha prevenido la relacione [sic] Villa de Laredo alas 12. del dia 8. de Abril de 1813.= Jose Antonio Venavides = Es Copia dela Relacion que me ha dirigido el Teniente D. Miguel Serrano q. ${ }^{\mathrm{e}}$ acavo de resibir $=$ Monterrey 11 de Ab. ${ }^{1}$ de 1813. = Bustaman te

\section{Es Copia}




\section{Translation for the Deposition of Guillermo Navarro}

Don José Antonio Venavides [sic] 2nd Lt. Third Mobile Company, Nuevo Santander, in view of the events at Bexar, has by order of Lt. Don Miguel Serrano, Commander of the above mentioned Company, and of the troops at this post, taken the deposition of Guillermo Nabarro [sic], veteran soldier of the Lampazos Company. [Navarro] is aide to Lt. Col. Don Geronimo de Herrera. Said soldier appeared in this city at twelve noon on April 8, 1813, having left Bexar on the fifth at 4:00 p.m.

[Navarro] was instructed to relate everything he knew and had seen of the events at Bexar. He said the following: On the third of this month, toward dark, he saw a party of mounted men on the march, consisting of about one hundred Americans as well as troops from La Bahia, Alamo, and Bexar. It was evident that Antonio Delgado, corporal from the troops at Bexar and (one word unintelligible) of the Alamo Company was in charge of this party. The party had a number of saddled horses with them, and they ordered the Governors and other officials to mount them. Included were Don Simón Herrera, Don Manuel Salcedo, Don Geronimo Herrera, Don Miguel de Arcos and his two sons, Don José de Goecaechea, Don Joaquin de Ugarte, Don Juan Ignacio de Arrambide, Don José Amador, and the artilleryman, Don Antonio López. Also, a Captain of the artillery group from Nueva Vizcaya. As soon as all of them had mounted, the party left for the place called La Tablita. About 9:00 a.m. of the following day, the aforementioned group [renegades] returned, bringing back the horses on which the Governors and other officials had been mounted. They were also carrying a number of personal items of apparel that were recognized by the respective assistants as having belonged to their Lordships the Governors. He states that Don Jayme [sic] Garza, Don Antonio Vilano, Lt. Ramires [sic], and 2nd Lt. //2 Padilla, Capt. Luis Galban and several others whose names he doesn't know were made prisoners. The party [renegades] proceeded to round-up more prisoners. Don Gaspar Flores warned Capt. Charles and Lt. Saldaña to leave town immediately to avoid imprisonment. Furthermore, he states that the troops which had been disarmed previously, as has already been declared, were gathered and given the option to join their [renegade] forces, or be penalized by not having their firearms returned to them, if they refused. Many, unwilling to forfeit their firearms, and already partial to the renegades, did join them. Excluding the troops from the Alamo, Bexar, and La Bahia, [Navarro] estimated the renegade units to consist of seven hundred Americans plus a number of Indians from the interior, plus a large number of Lipan Apache. Nabarro [sic] states that the homes of Europeans and Creoles were plundered, and livestock was scattered. Nabarro [sic] overheard the renegades to say that in three months they intended to go to the Presidio at Rio Grande. He also stated that he heard them express anxiety about reaching Monclova. When asked if he had more to relate, he said no. $\mathrm{He}$ stated that all that he related was the truth as best he had seen and remembered.

Villa de Laredo José Antonio Venavides [sic] 8 April 1813 12:00 noon 
This is a copy as requested by Lt. Miguel Serrano, and which I have just received at Monterrey. 11 April 1813. Bustamante

\section{COPY}

Arrendondo

(Rubric) 


\section{Transcription for the Proclamation}

Proclama.

Fidelisimos Criollos, naturales de esta delisiosa America, que gemis aletargados en la brumosa carga del Yugo Europeo: despertad al sonido que a buestros Vmbrales se ha acordado aconvidaros con la gloriosa Yndepend. ${ }^{a}$ que tan felisez principios vá teniendo: No hagais apresio de algunos inconsiderados que os procuran alusinar con el pretesto de que es justa la Causa que se han propuesto contra todo derecho natural esos egocitas [sic] vajo cuyo capricho haveis vivido tanto tiempo sumergidos. Abrid los Ojos y conosereis que todo su anelo és Sacrificaros despues de haverse hecho poderosos con vuestros afanes y tareas. Tended la vista alos susesos ocurridos desde Agosto del Año pasado, y sin dexar de admiraros, vereis como a pesar de los mayores esfuerzos que puso esta Provincia para oponerse ala Yndepend. ${ }^{\text {a }}$, todos han sido favorables resultados para la Nazion, y pesarosos para los Sacrificadores de sus //avitantes Si, Si: El Comandante de Nacogdoches nó aguardo a que nuestros aliados los Valientes Anglo Americanos pisasen á aquel suelo para salir fugado, avandonando todo, no lo ignorais pues fue publico. Reunidas las pequeñas fuerzas que en aquel Pueblo se encontraron huvieron de penetrar estas sin ningun obstaculo hasta el Presidio de la Bahia, y quedaron fustradas las Esperanzas de vuestros opresores, que con mil Soldados salieron de esta Capital á encontrarse con un pequeño de Patriotas que solo por vuestra libertad se han ofresido á Sacrificar sus vidas: Recordad que en tres mesesy medio del mas obstinado sitio en el mas riguroso del imbierno, no fué otra cosa que sacrificar hombres al capricho de una temeridad, y que en fruto fue avandonado, teniendo el Gov. ${ }^{\text {or }}$ Salcedo del mil doscientos hombres de operasion; quando pocos dias antes havia intentado varios Ataques decisivos que nunca puso en practica. En fin la batalla de Salado, el 29 de Marzo dia memorable para dos Siglos venideros: ¿No os extremeseis al ver la Completa derrota de novecientos sincuenta hombres vien Armados con seis Pzas. de Artilleria que manejaban con veloci- $/ /^{3}$ dad y destreza? Preguntad alos dispersos que por esos lugares se habran aparesido, y estareis entendidos del valor de estos eroes que no les aterroiza ni el Estallido del Cañon ni el Silvido de las Valas; Desgrasiado Campo en el que fueron Sacrificadas tantas Victimas de Criollos ala Yndiscrecion de un tirano q. ${ }^{e}$ avia tenido a tantos hombres engañados! Abrid los Ojos y no os opongais ala fuerza, tomad exemplo de la Patriotica Ciudad de San Fernando de Bexar q. ${ }^{\mathrm{e}}$ sin gastar un tiro de fucil dió paso franco al Exercito y evitó la Sangre que era consiguiente derramar. Escusa tomar las Armas para vuestros hermanos que ya respiran en esta Prov. ${ }^{a}$ el ambiente de la Yndepend. ${ }^{a}$ y comprar los progresos adquiridos en tan poco tiempo con un Corto numero de hombres, que dieron principio a esta gloriosa empresa, con el que ahora contiene para continuarla; pues de dia en dia se vá aumentando y se acresentará en tal grado, que su poder Señoreará a buestros Opresores, y a cuantos incautos se les agreguen. No deis lugar a que sobre vuestro 
paiz vengan las numerosas fuerzas que yá Cautivan para reunirse á ayudarnos á sacudir el yugo de //vuestra Exclavitud. Todas las Nasiones de Yndios están preparadas con las Armas en la mano en favor nuestro y porque no causen perjuicios que os sean sencibles se há evitado su reunion: La fuerza que deseo vsar para convene la Nacion Mexicana és la voz de la rason, y del desengaño.

Ciudad de San Fernando 22 de Abril de 1813 y $3 .^{\circ}$ de nuestra Yndependencia.

José M. ${ }^{\text {a }}$ Guadiana (Rúbrica)

Sarg ${ }^{\text {to }}$ Mayor

Ysidro dela Garsa (Rúbrica)

Com. $^{\text {te }}$ de $\mathrm{Mil}^{\mathrm{S}}$ auxili. ${ }^{\mathrm{s}}$

José Ygnacio de Abal (Rúbrica)

Juan Melendez (Rúbrica)

Juan José Tixerinas (Rúbrica)

Tomas Oquillas (Rúbrica)

Crecensio Vargas (Rúbrica)

José Felis Peñes (Rúbrica)

Josef M. ${ }^{\mathrm{a}}$ Muñoz (Rúbrica)
José Manuel Prieto (Rúbrica) Ayud. ${ }^{\text {te }}$ mayor de plaza

José Nicolás Benites (Rúbrica)

Luis Cantu (Rúbrica)

Mig. ${ }^{1}$ Cortina (Rúbrica)

Rafael Alvarado (Rúbrica)

José Ant. ${ }^{\circ}$ Guerra (Rúbrica)

Bernardino Benavides (Rúbrica)

Pedro Arispe (Rúbrica)

Lucas Cantu (Rúbrica) 
Most loyal Creoles, natives of this enchanting America, how you weep under the lethargic and oppressive weight of the European yoke. Awaken to the sound which gathers at your threshold, and prompts you to join that glorious independence movement which has been having such joyous beginnings. Pay no heed to those few ignorant ones who attempt to delude you with a pretext of a just cause which they have espoused, against all natural laws, and under whose egotistical whim you have lived subjugated for so long. Open your eyes to the recognition that their only wish is to sacrifice you inspite of having attained their power from your effort and labor. Focus your attention on the events that have transpired since August of last year. Don't be surprised to find that in spite of the tremendous effort exerted by this Province to oppose independence, the results have been favorable for the nation, and lamentable for the sacrificers of its citizenry. Oh! yes. Oh! yes. The Commander at Nacogdoches did not even wait for our valiant Anglo American allies to set foot on that land before he ran away, abandoning everything. Surely you know this. It was public knowledge. The small forces remaining in that town could have penetrated all the way into Presidio La Bahia, without anything to hold them back, thwarting the hopes of your oppressors. With a thousand soldiers [those oppressors] departed from that capital to find themselves confronted by a small [force] of patriots, whose only interest in sacrificing themselves was to help you obtain your freedom. Keep in mind that in three and one half months from the most obstinate siege, during the coldest month in Winter, the attempt was a sheer sacrifice of men's lives. A reckless and abortive whim. Even though Governor Salcedo had at his disposal twelve hundred men for tactical maneuvers, and only a few days earlier planned several decisive attacks, he never carried them out. Finally, the Battle of Salado, on 29 March. A memorable day for two generations to come. Does it not give you pause to see the complete defeat of nine-hundred and fifty well armed men, with six pieces of artillery which they handled speedily and adeptly? Ask those who scattered, and who have since reappeared around those parts, and you will be informed of the valor of those heroes, not daunted by either cannon or artillery fire. Oh! ill-fated site, where so many Creoles fell victim to the senselessness of a tyrant who had managed to fool so many men. Open your eyes and don't oppose strength. Follow the example of the patriotic city of San Fernando de Bexar, which without firing one single shot allowed the army free passage, thereby avoiding the blood bath that would have ensued. Justify taking up arms for your brethern who are already breathing the air of independence in this Province. Accept the progress made in such a short time by that small number of men who began this glorious effort and who still have the strength to continue. Day by day their numbers grow, and soon they will grow to such a degree that their power shall overrule that of your oppressors, and all those ill-informed enough to join them. Don't allow your land to be overtaken by the numerous forces which have been gathered and are lining-up to join force to help us shake the yoke of your slavehood. All the Indian Nations have been lined-up, with arms at hand on our side, and so that they won't cause you irreparable damage, they have been dispersed. The only force I wish to use to convince the Mexican Nation, is the voice of reason, and the realization of truth. 
City of San Fernando

22 April 1813, Third of our Independence.

José Maria Guadiana (Rubric)

Seargeant Major

Isidro de la Garza (Rubric)

Commander of Volunteers

José Ignacio Abal (Rubric)

Juan Melendez (Rubric)

Juan José Tixerina (Rubric)

Luis Cantu

Miguel Cortina

Rafael Alvarado

José Antonio Guerra

Bernardo Benavides

Pedro Arispe

Lucas Cantu
Tomás Oquillas (Rubric)

Crecensio Vargas (Rubric)

José Felis Penes (Rubric)

Josef María Munoz (Rubric)

José Manuel Prieto (Rubric)

Chief Volunteer at the Plaza

José Nicolas Benites (Rubric) 
BURIAL OF SIMON HERRERA, AUGUST 28, 1813 (SFCBR entry 540)

Holograph

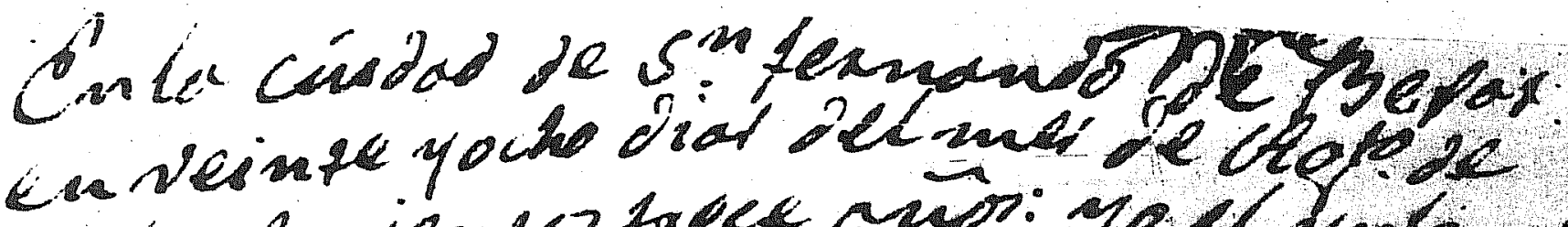

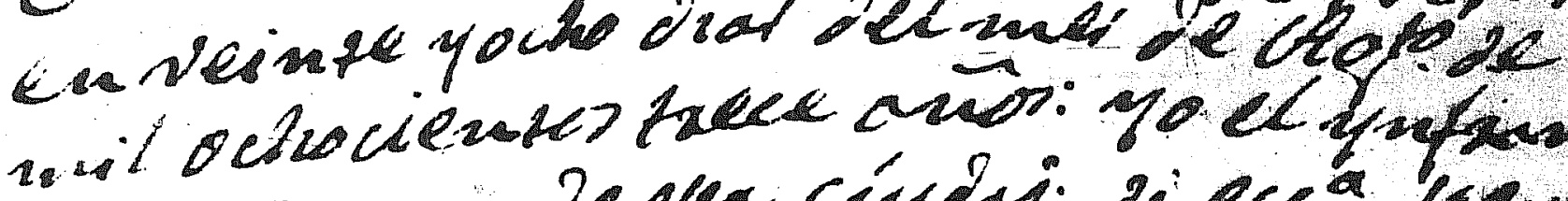

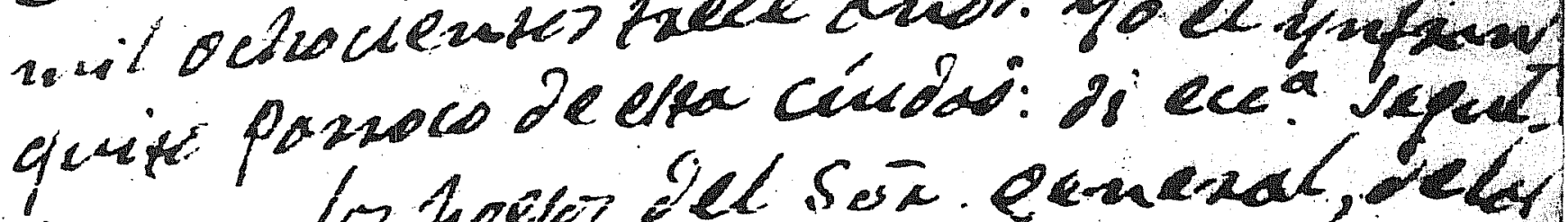

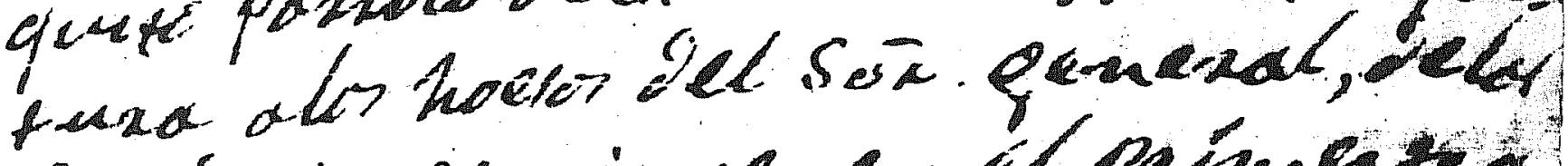

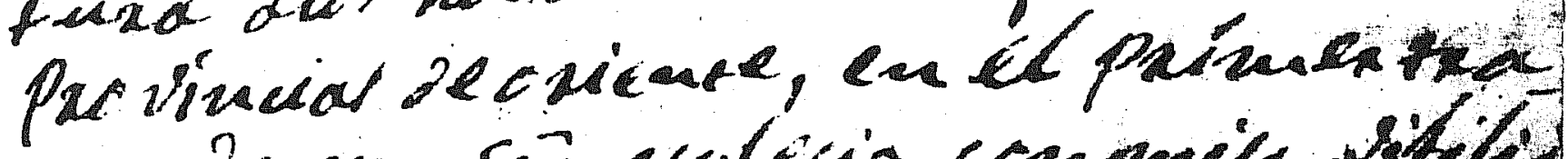

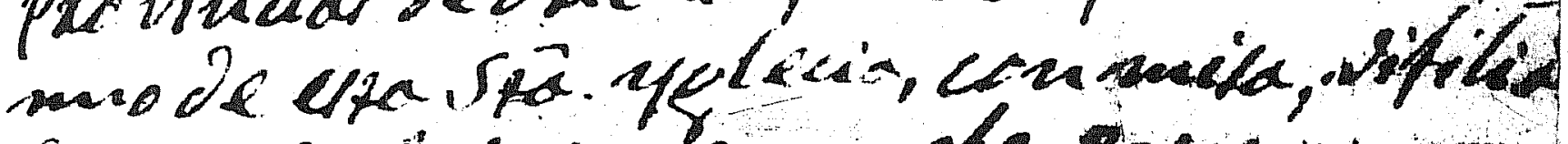

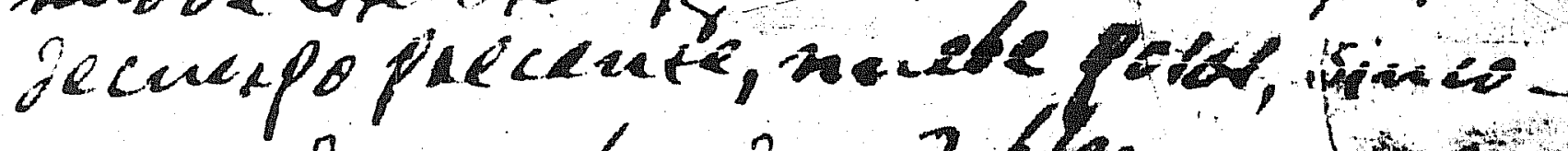
meded detwaba, ioce dobler

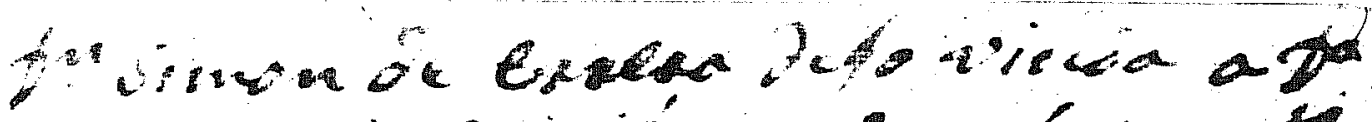

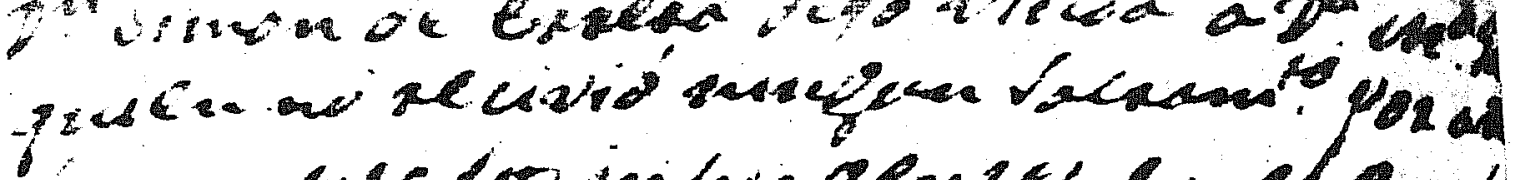

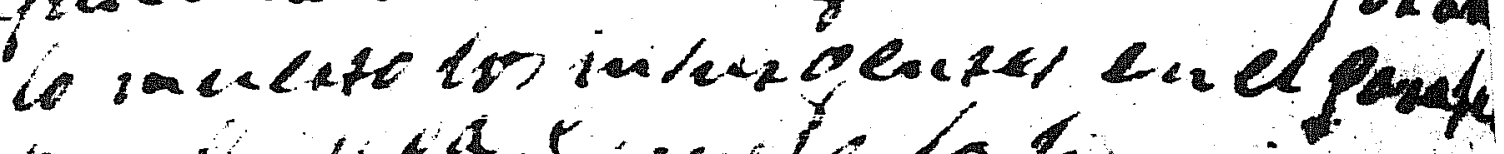

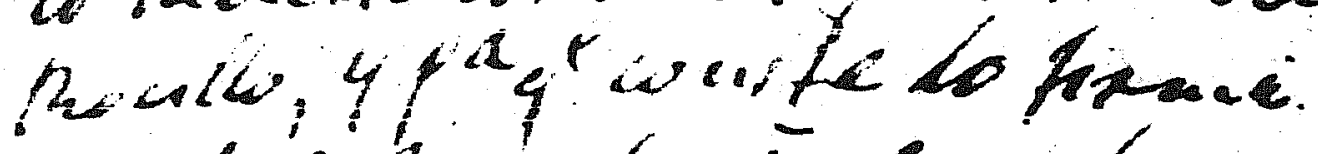

pill Tese toxic "Sambans

质.

27 


\section{Transcription for the Burial of Simón Herrera}

En la ciudad de $\mathrm{S}^{\mathrm{n}}$ Fernando de Bexar en veinte y ocho dias del mes de $\mathrm{Ag}^{\text {to }}$ de mil ochocientos trece años: yo el infra scripto parroco de esta ciudad: di ecc ${ }^{\mathrm{a}}$ sepul tura a los hoesos del $S^{\text {Or }}$ General de las Provincias de oriente, en el primer tra mo de esta $S^{\text {ta }}$ Yglesia, con misa, vijilia de cuerpo presente, nuebe pasos, sinco misas de tumba, doce dobles mayores Dñ Simon de errera dejo viuda a $\mathrm{D}^{\mathrm{a}} \mathrm{M}^{\mathrm{a}}$ quien no recivio ningun sacr ${ }^{\text {to }}$ por aver lo muerto los ynsurgentes en el paraje del Rocillo. Y para que conste lo firme

Br. José Darío Sambrano [sic]. (Rubric) 


\section{Translation for the Burial of Simón Herrera}

On the 28th of August, 1813, in the city of San Fernando de Bexar, I, the undersigned, parish priest of said city, gave Christian burial, in the first section of this holy church, to the remains of the General of the Eastern Provinces. Devotional services included a mass, a parishioner's vigil, nine stations of the cross, five funeral masses, plus twelve double high masses. Don Simón Herrera was survived by his widow, Doña María. The deceased had not received last rites, as he had been executed by insurgents at the place called Rosillo.

In confirmation thereof, I hereby affix my signature.

Fr. José Darío Zambrano (Rubric) 
BURIAL OF MANUEL SALCEDO, AUGUST 28, 1813 (SFCBR entry 539)

Holograph

4.93911

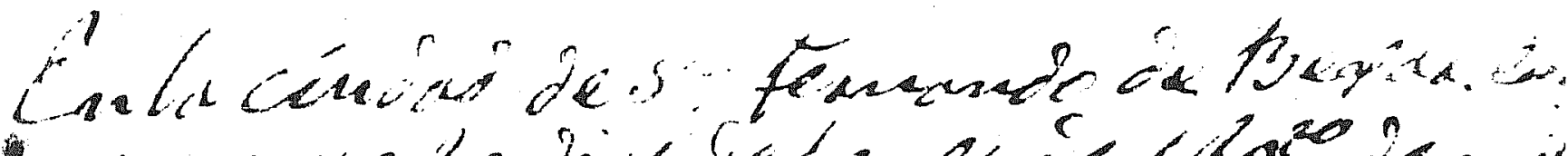

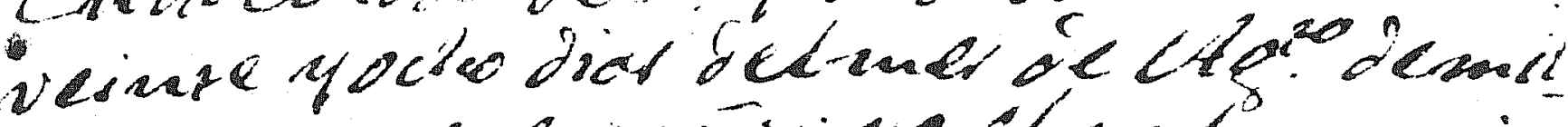

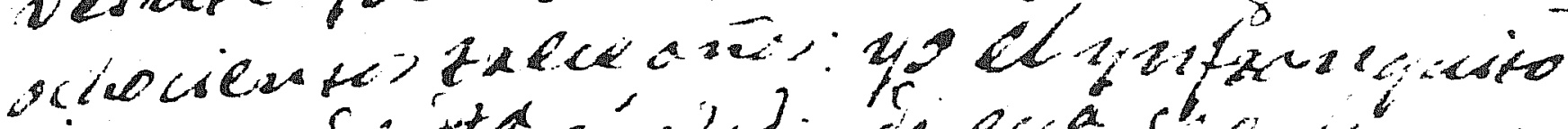

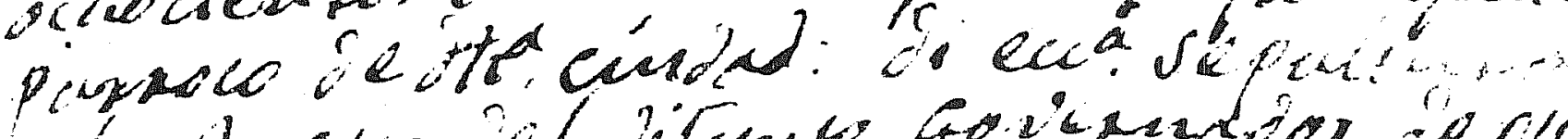

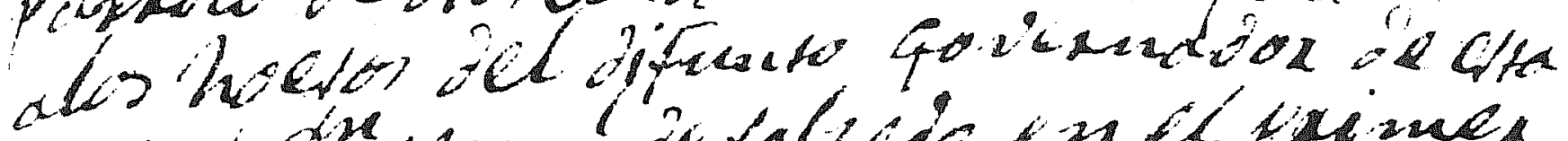

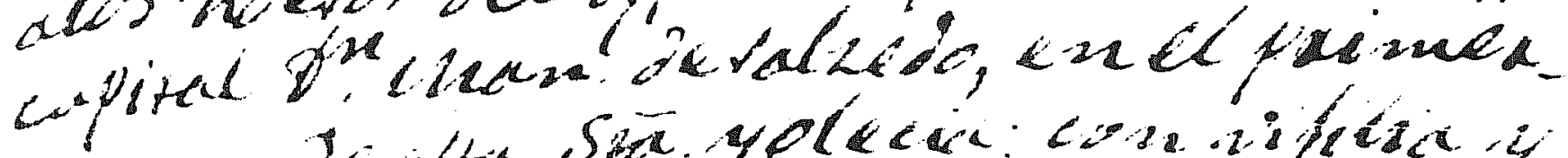

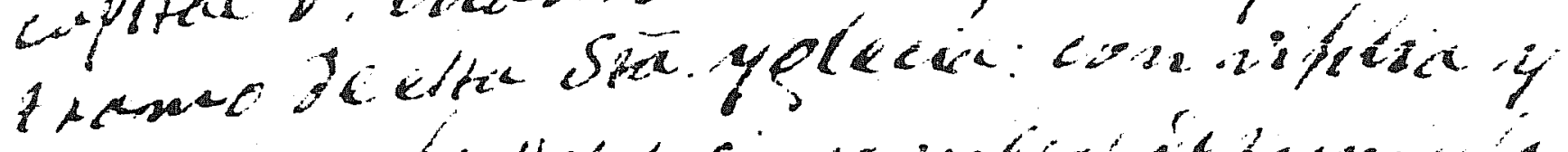

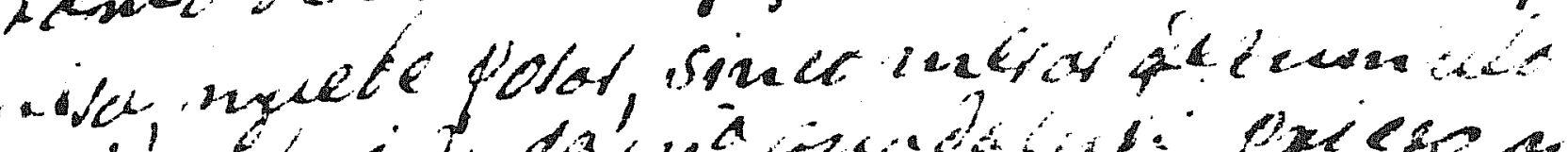

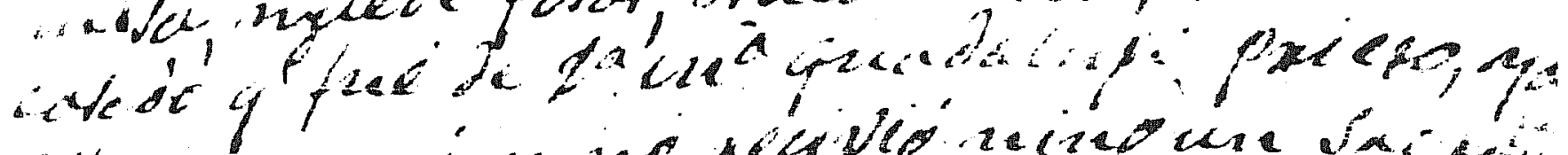

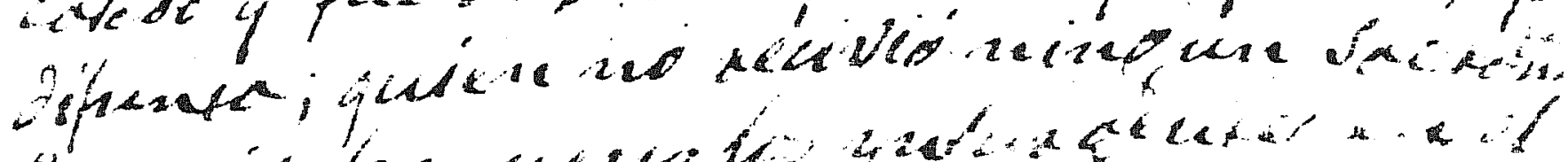

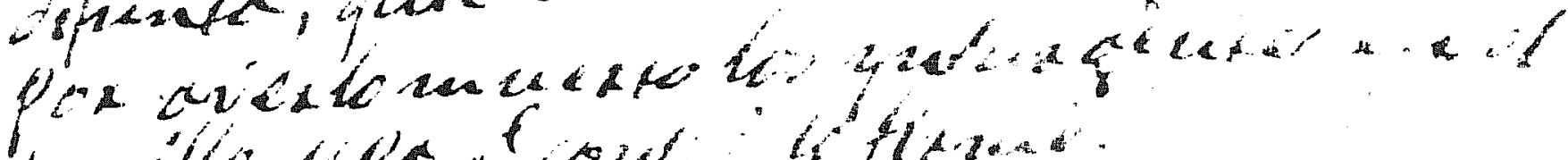

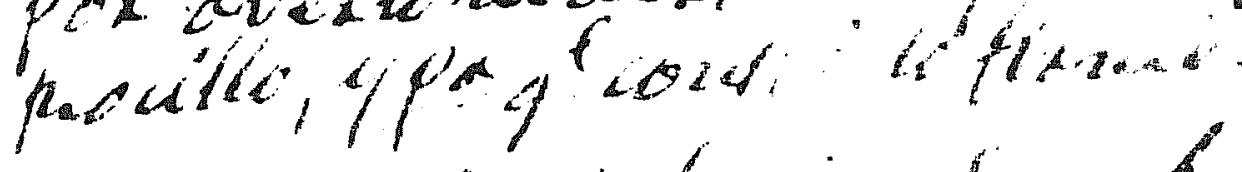

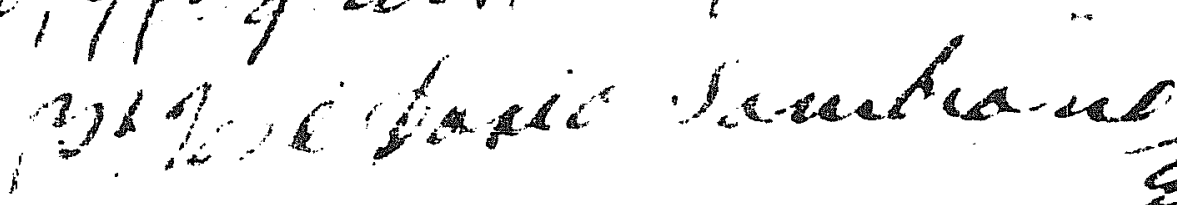

30 
Transcription for the Burial of Manuel Salcedo

En la ciudad de $S^{\mathbf{n}}$ Fernando de Bexar en veinte y ocho dias del mes de $\mathrm{Ag}^{\text {to }}$ de mil ochocientos trece años, yo el infrascripto parroco de $\mathrm{dh}^{\mathrm{a}}$ ciudad, di ecc ${ }^{\mathrm{a}}$ sepultura a los hoesos del difunto Governador de esta capital $D^{\mathfrak{n}}$ Man. de Salzedo [sic], en el primer tramo de esta $\mathrm{St}^{\mathrm{a}}$ Yglesia: con vijilia y misa, nuebe pasos, sinco misas funebres casado que fue de $D^{\mathrm{a}} \mathbf{M}^{\mathrm{a}}$ Guadalupe prieto ya difunta; quien no recivio ningun sacramento por averlo muerto los ynsurgentes en el Rocillo, y $\mathrm{p}^{\mathrm{a}} \mathrm{q}^{\mathrm{e}}$ conste lo firme.

Br. José Darío Sambrano (Rubric) 


\section{Translation for the Burial of Manuel Salcedo}

On the 28th of August, 1813, in the city of San Fernando de Bexar, I, the undersigned parish priest of said city did give Christian burial, in the first section of this holy church, to the skeletal remains of the deceased Governor of this capital, Don Manuel Salcedo. Devotional services included a mass, nine stations of the cross, plus five funeral masses. He had been married to the late Doña María Guadalupe Prieto. The Governor had not received last rites as he had been executed by insurgents at Rosillo.

In confirmation thereof, I hereby affix my signature.

Br. José Darío Zambrano (Rubric) 
GROUP BURIAL OF THE ROSILLO DEAD, AUGUST 28, 1813 (SFCBR entry 541)

Holograph

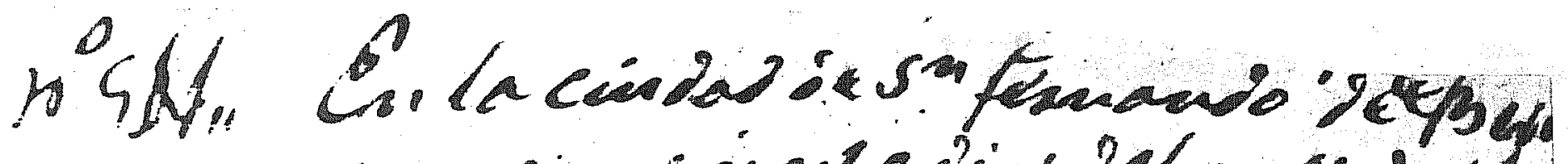

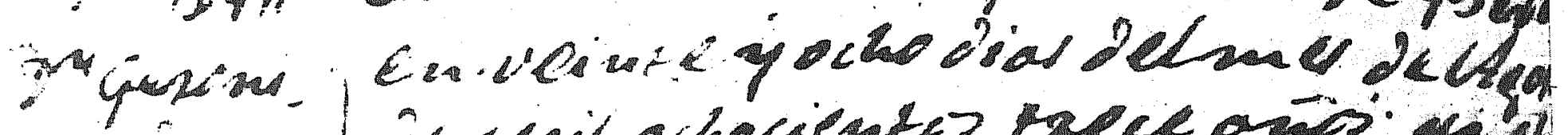

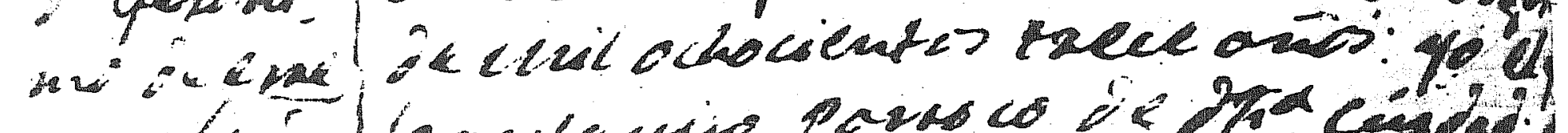

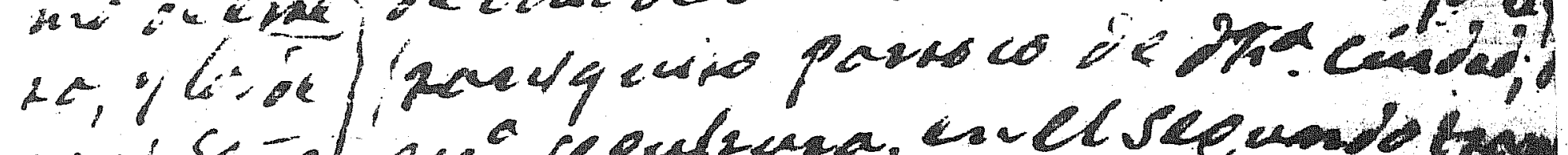

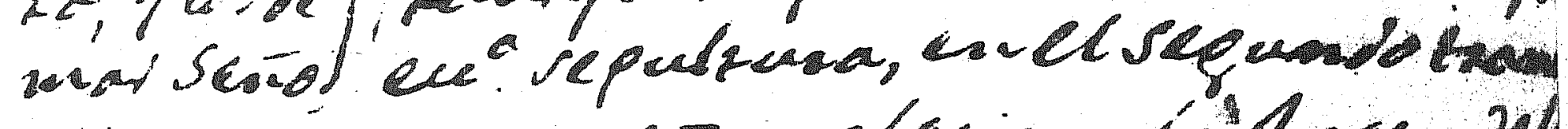

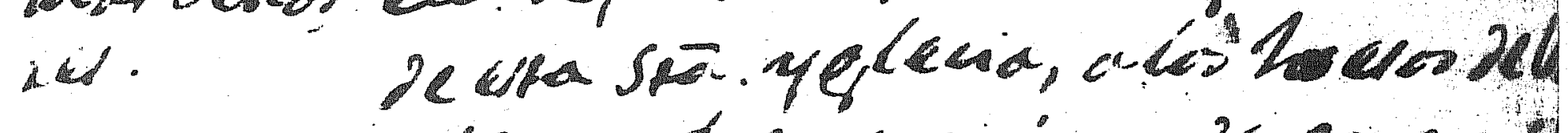
Difunares D. Guexainins de exacag,

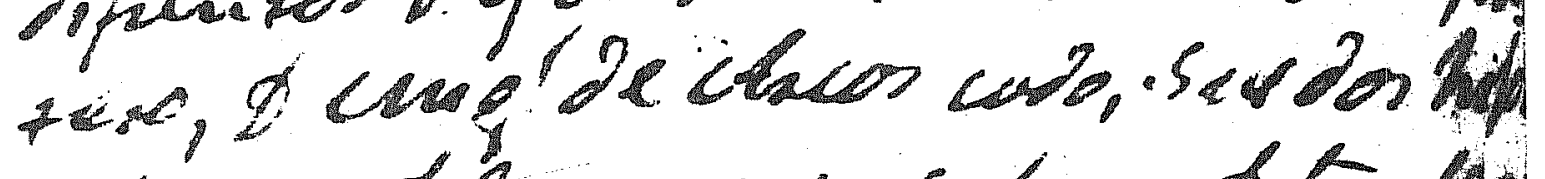

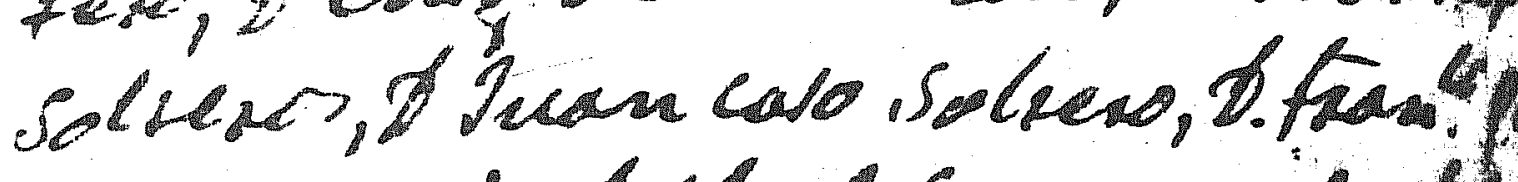

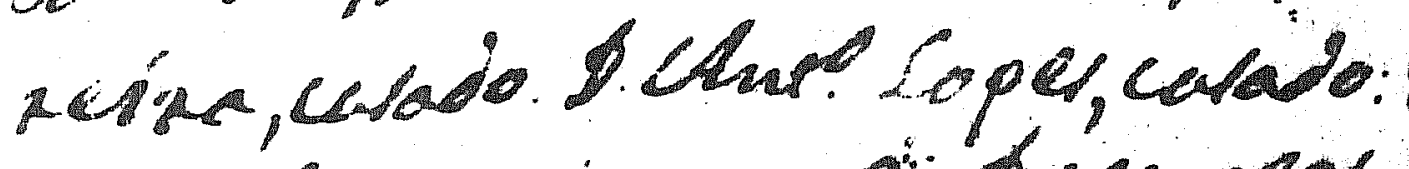

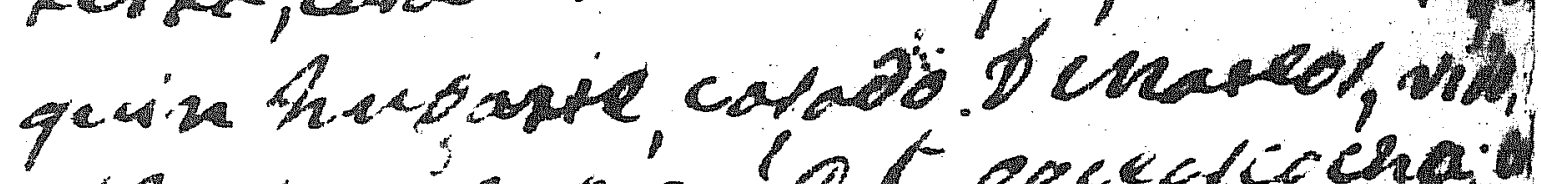
elterientecoron! D. F. gocedichail

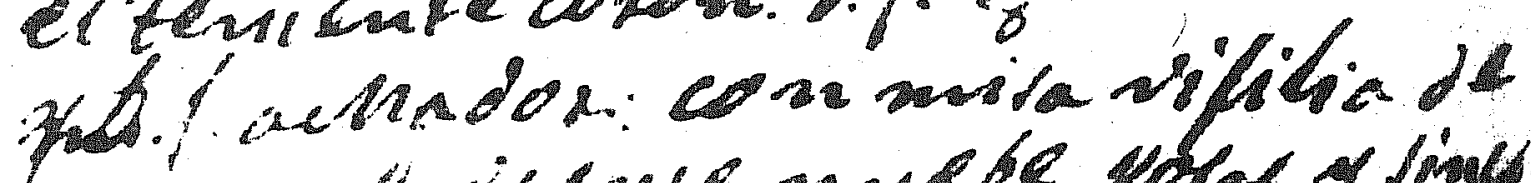

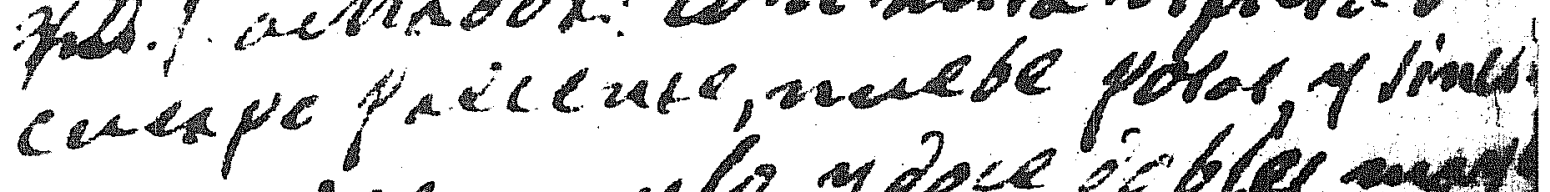

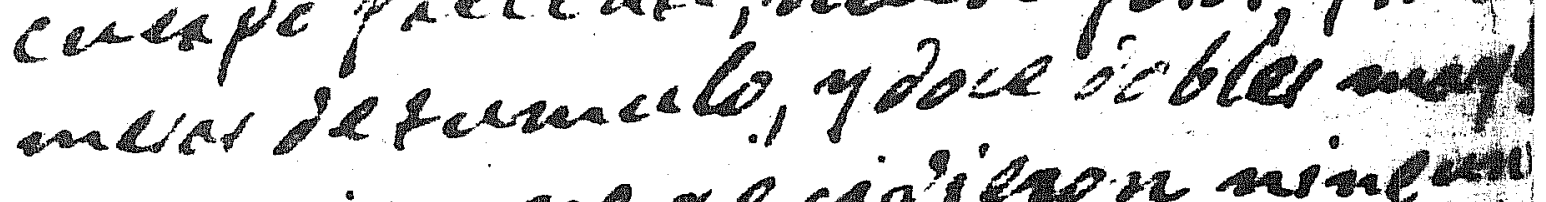

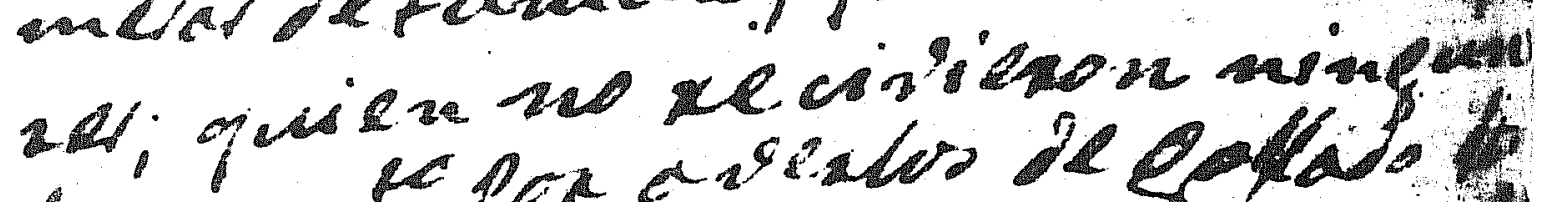

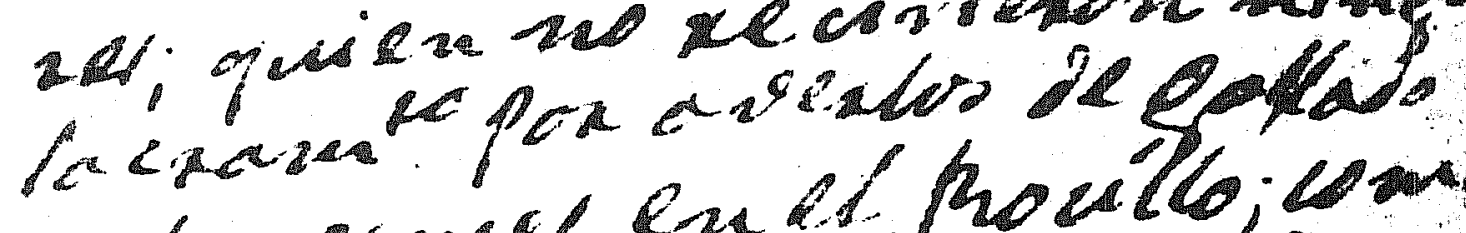

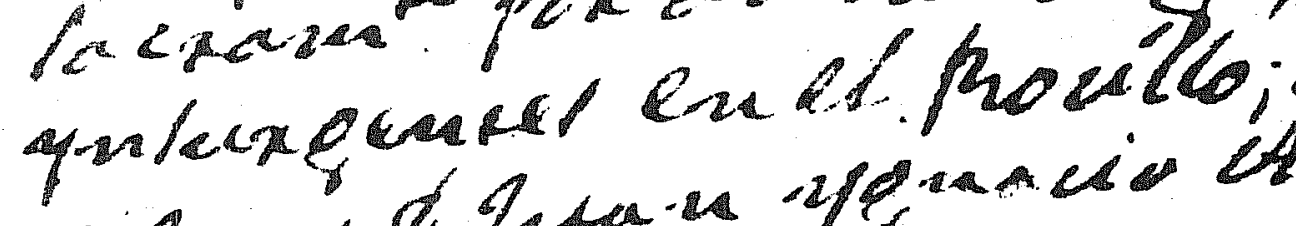

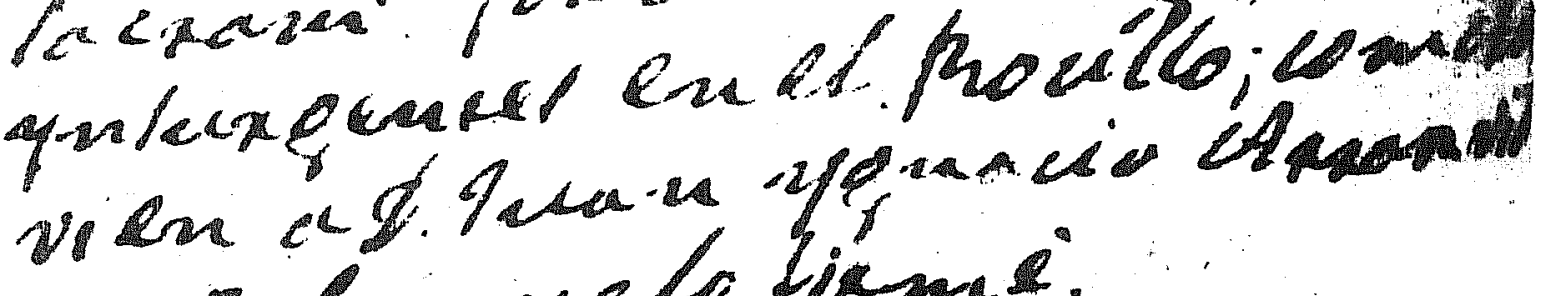
ip pl. constelo firmes:

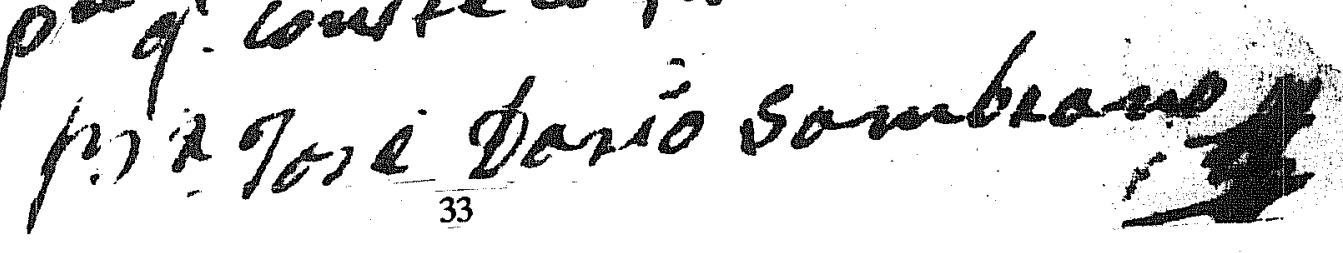




\section{Transcription for the Group Burial of the Rosillo Dead}

En la ciudad de $\mathrm{S}^{\mathrm{n}}$ Fernando de Bexar en veinte y ocho dias del mes de Agosto de mil ochocientos trece años. Yo el infrascripto parroco de $\mathrm{d}^{\text {ha }}$ ciudad, di ecc ${ }^{\mathrm{a}}$ sepultura en el segundo tramo de esta St ${ }^{\mathbf{a}}$ Yglesia, a los hoesos de los difuntos D. Geronimo de errera, sol tero, D. Mig ${ }^{1}$ de Arcos, casado, sus dos hijos solteros, D. Juan Caso soltero, D. Fran. ${ }^{\mathrm{CO}} \mathrm{Pe}$ reira, casado, D. Ant ${ }^{\circ}$ Lópes [sic], casado, D. Joa quin Hugarte [sic], casado. D. Marcos, viudo el Teniente Coronel D. J. Goecaechea (one word illegible), D. J. Amador: con misa, vijila de cuerpo presente, nuebe pasos, y sinco misas funebres y doce dobles mayo res; quien no recivieron ningun sacrm $^{\text {to }}$ por averlos degollado los ynsurgentes en el Rocillo; como tan vien a D. Juan Ygnacio Arrambide Y para que conste lo firme.

\section{Br. José Darío Sambrano (Rubric)}

\section{Translation for the Group Burial of the Rosillo Dead}

On the 28th of August, 1813, in the city of San Fernando de Bexar, I, the undersigned parish priest of said city, did give Christian burial, in the second section of this holy church, to the skeletal remains of the following deceased: Don Geronimo de Herrera, single; Don Miguel de Arcos, married; his two sons, single; Don Juan Caso, single; Don Francisco Pereira, married; Don Antonio López, married; Don Joaquin Ugarte, married, Don Marcos, widower; Lt. Col. Don J. Goecaechea, (one word illegible); Don J. Amador. Devotional services included a mass, a parishioner's vigil, nine stations of the cross, five funeral masses, plus twelve double high masses. The deceased had not received last rites as they had been executed by insurgents at Rosillo. Their throats had been slashed. Including that of Don Juan Ignacio Arrambide.

In confirmation thereof, I hereby affix my signature

Br. José Darío Zambrano (Rubric) 
PERMISSION FOR A CHRISTIAN BURIAL, MARCH 9, 1814 (Bexar County Archives microfilm reel 53, frame 0554)

Holograph

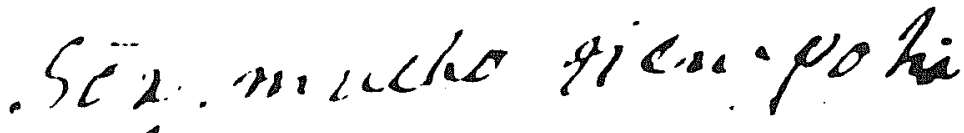

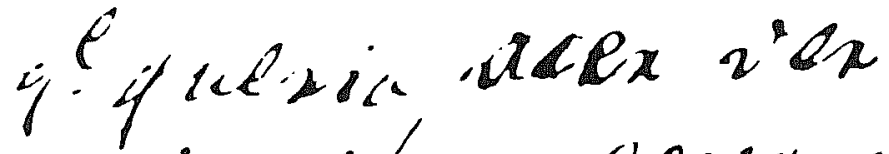

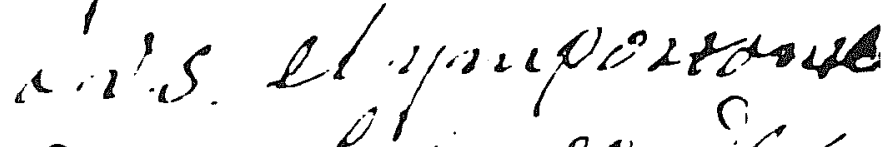

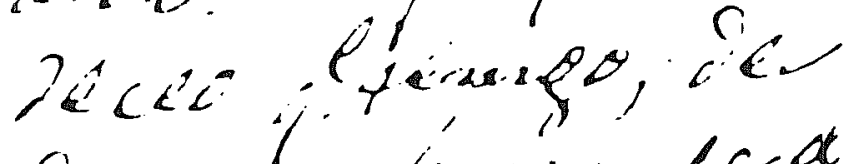

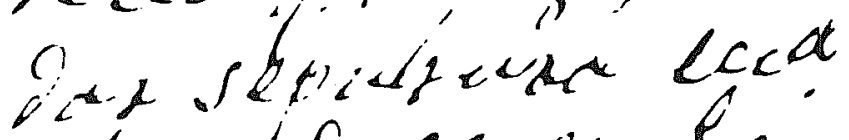

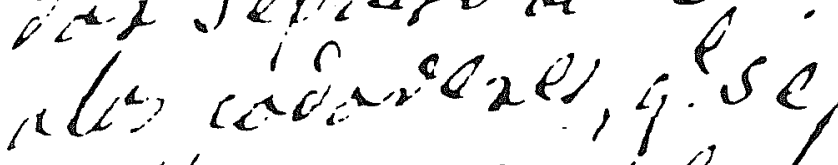

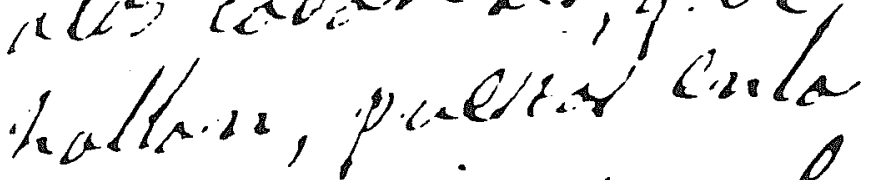

$$
\begin{aligned}
& \text { plata; pasincos }
\end{aligned}
$$

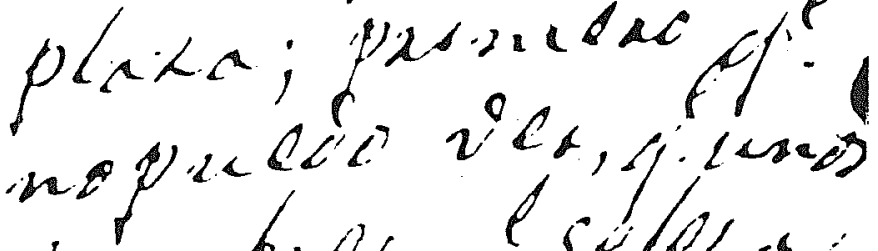

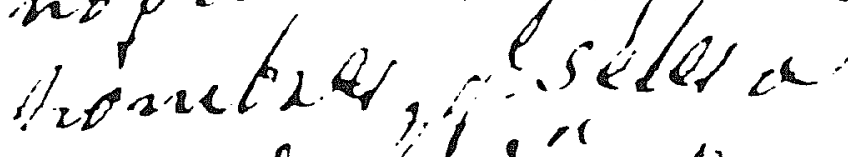

$$
\begin{aligned}
& \text { quationde talca dea }
\end{aligned}
$$

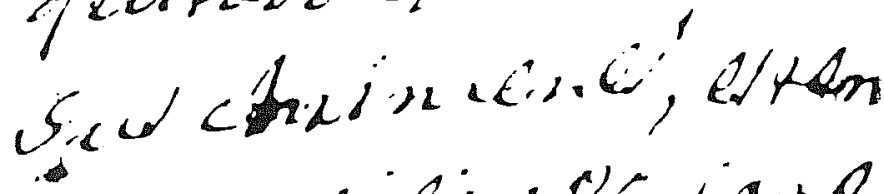

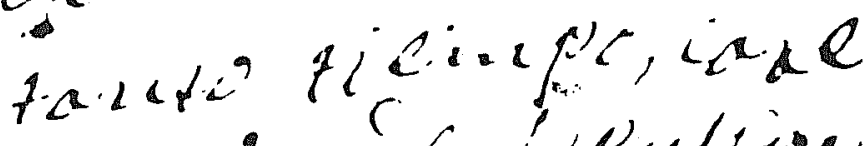

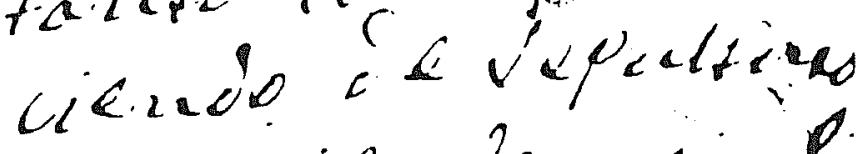

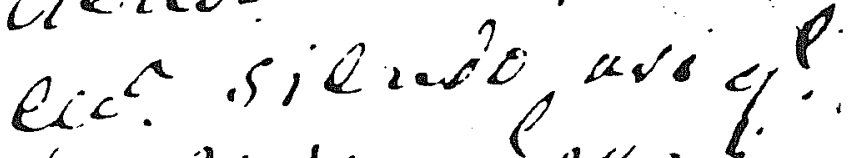

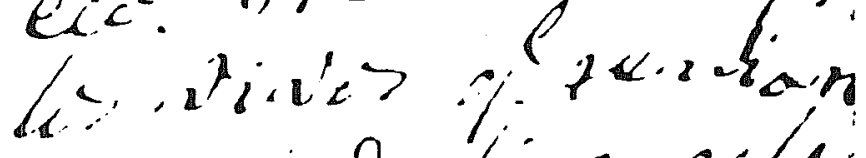

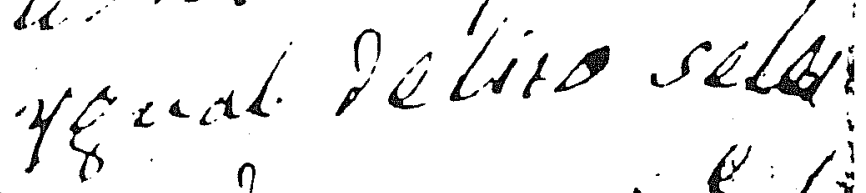

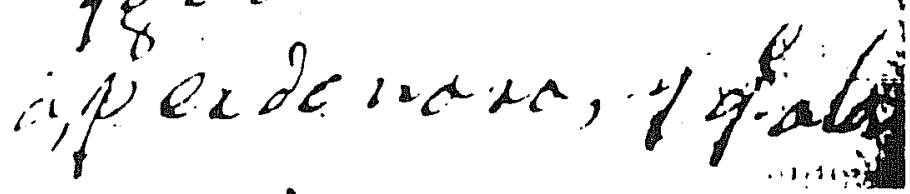

35 
Holograph (continued)

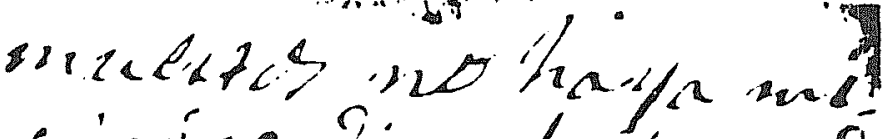

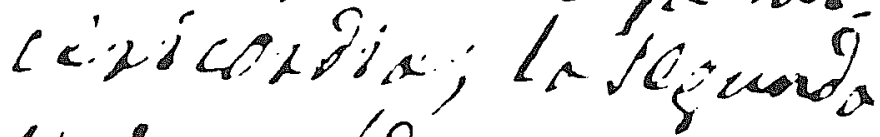

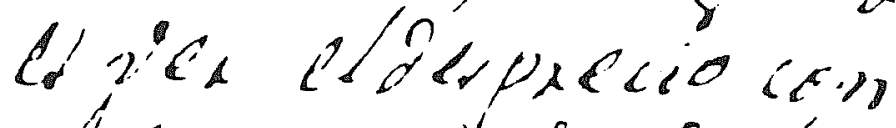

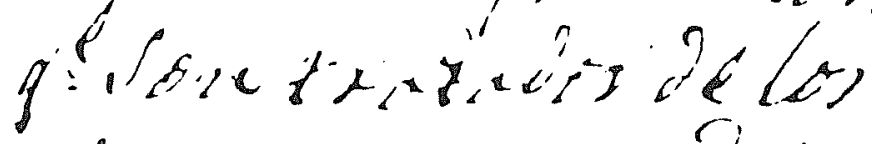

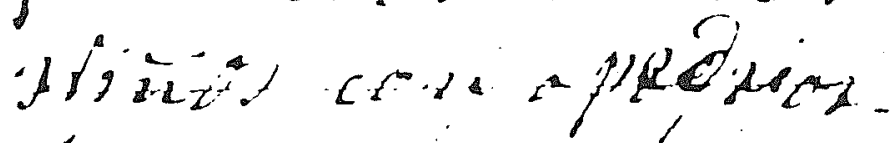

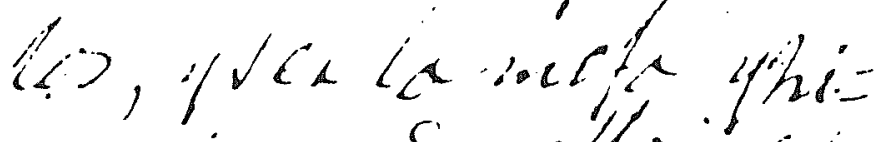

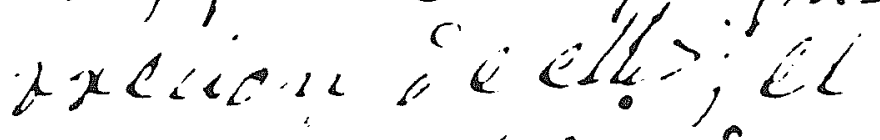

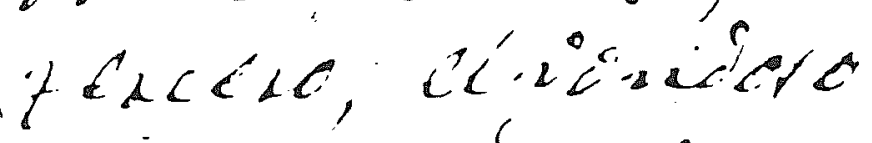

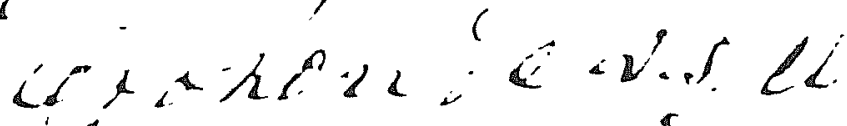

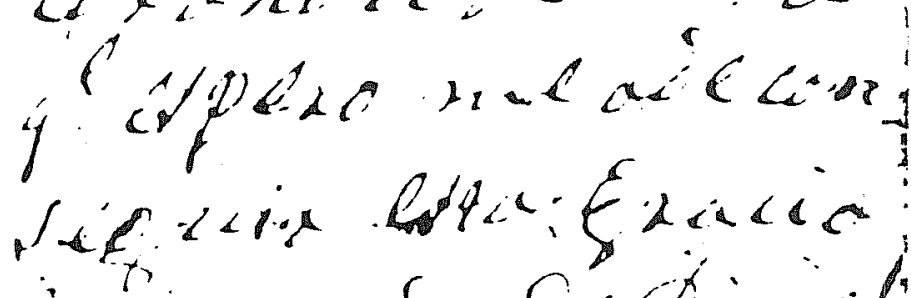

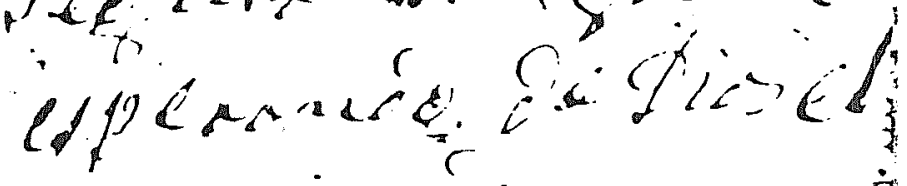

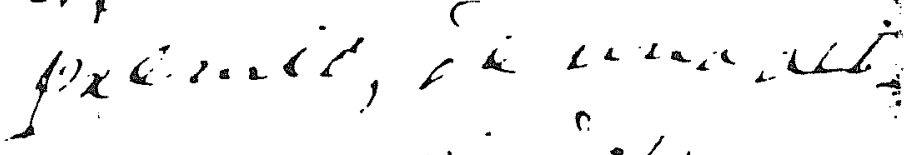

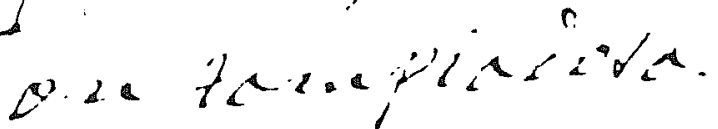

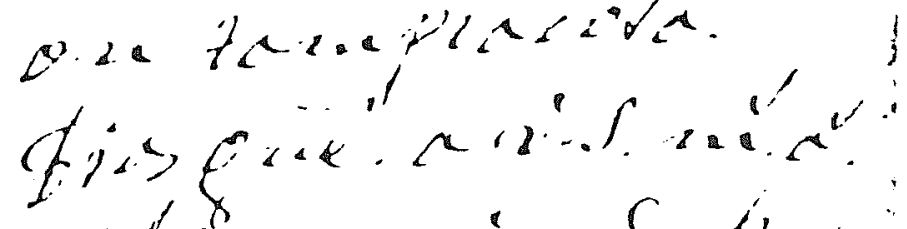

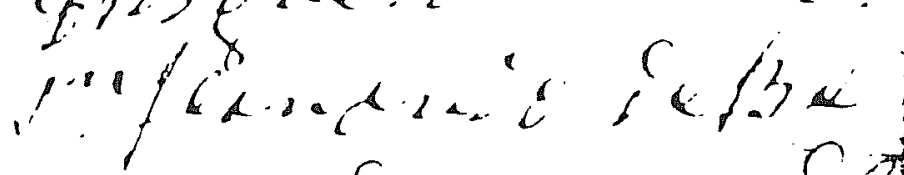

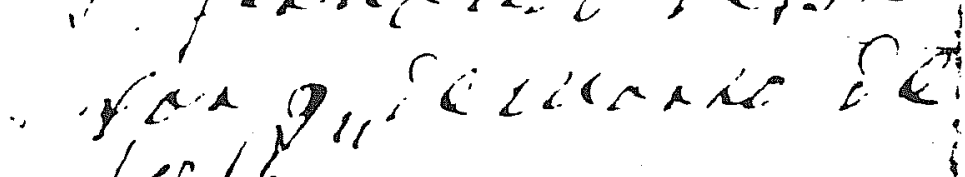

$166 / K_{11}$

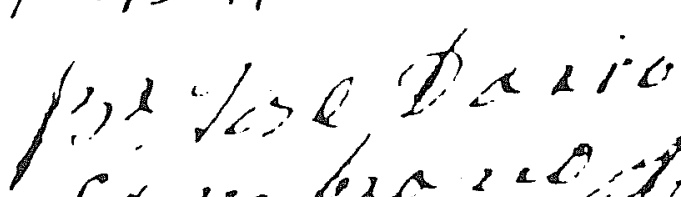

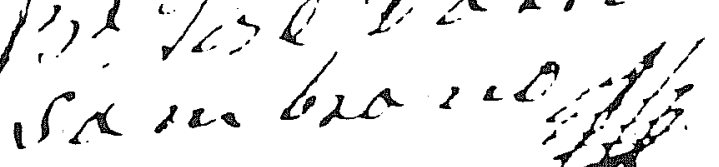

ii)

36 


\section{Transcription for Permission for a Christian Burial}

Sór. mucho tiempo ha

q. queria acer ver

a V.S. el ymportante

deceo q. ${ }^{e}$ tengo, de

dar sepultura ecc. ${ }^{a}$

a los cadaveres q. ${ }^{\mathrm{e}}$ se

hallan, puestos en la

plaza; primero q.

no puedo ver, $q$. unos

hombres q. ${ }^{e}$ se les a

quitado la vida por

sus chrimenes esten

tanto tiempo care

ciendo de sepultura

ecc. ${ }^{a}$ siendo asi q.

los vivos q. ${ }^{\mathrm{e}}$ tenian

igual delito seles

a perdonado y $\mathrm{q} .{ }^{\mathrm{e}}$ alos.

Muertos no haya mi

cericordia, lo segundo

es ver el desprecio con

q. . son tratados de los

niños con apedriar

los y ser lo (two words illegible) y ni

rrecion de ellos; el

tercero, el (three words illegible)

de V.S. el

q. ${ }^{\text {e }}$ espero me a de con

seguir esta gracia

esperando de Dios el

premio de una aci

on tan piadosa

Dios que a V.S. m. ${ }^{a}{ }^{\text {a }}{ }^{\mathrm{s}}$

S. ${ }^{\mathbf{n}}$ Fernando de Bexar

B. ${ }^{\mathbf{r}}$ José Darío Sambrano

9 de Marzo de 1814. 
Most Excellent Sir:

For quite a while I have been wanting to point out to His Excellency

my strong desire to give Christian burial to the corpses in the

plaza. To begin with, it is hard for me to understand how Christian burial

has been denied a group of men who were put to death for their crimes,

while at the same time others are running around, guilty of the same crimes, but have been

pardoned. Why deny that mercy to the dead. Secondly, it is hard for me to watch the disdain

with which the corpses are treated by children, who throw rocks at them.

Thirdly, (three words illegible) of His Excellency. I hope

His Excellency will grant me that favor. God should grant such a

merciful act. May God grant His Excellency a long life.

San Fernando de Bexar

B. ${ }^{\mathbf{r}}$ José Darío Sambrano (Rubric)

9 March 1814. 


\section{REFERENCES CITED}

Gutiérrez de Lara, J. B. M.

1812- Historia, Operaciones de Guerra, Arredondo. No. 903. Gutiérrez de Lara collection, Eugene 1813 C. Barker Texas History Center, The University of Texas at Austin.

Bexar County Archives

Microfilm located at the John Peace Library, The University of Texas at San Antonio.

Haggard, V. J.

1941 Handbook for Translators of Spanish Historical Documents. Semco Color Press, Oklahoma City, Oklahoma.

San Fernando Cathedral Burial Records (SFCBR)

1802- Microfilm. John Ogden Leal, translator. Office of the County Clerk, Bexar County 1817 Courthouse, San Antonio, Texas. 




